CARLOS F. DIAZ-ALEJANDRO

Columbia University

\title{
Latin American Debt: I Don't Think We Are in Kansas Anymore
}

BLAMING VICTIMS is an appealing evasion of responsibility, especially when the victims are far from virtuous. But when sins are as heterogeneous as those of the Latin American regimes of 1980, one wonders how well the exemplary mass punishment fits the alleged individual crime. Most Latin American economies, for a variety of domestic and external reasons, in 1980-81 faced the need for reform and adjustment to the new international economic environment. However, the response was slow, and policy errors continued to be made. Yet the incompetence and torpor of policymakers do not fully explain the depth of the depression of the early 1980s in Latin America and the mediocre outlook for recovery.

This paper will argue that what could have been a serious but manageable recession has turned into a major development crisis unprecedented since the early 1930s mainly because of the breakdown of international financial markets and an abrupt change in conditions and rules for international lending. The nonlinear interactions between this unusual and persistent external shock and risky or faulty domestic policies led to a crisis of severe depth and length, one that neither shocks

I am grateful to Barry Adams, Andres Bianchi, Edmar Bacha, William Cline, Jose Antonio Ocampo, Alan Stoga, Guillermo Calvo, Maurice Obstfeld, Michael Klein, Vahid Nowshirvani, Laurence M. Weiss, Miguel Rodriguez, Jeff Frieden, Ernest Stern, Francisco Lopes, Ernesto Zedillo, Alberto Fracchia, Manuel Marfan, and Ted Truman for much help. Members of the Brookings Panel also provided many constructive suggestions. 
nor bad policy alone could have generated. Large capital outflows, in most cases encouraged by unconditional currency convertibility, provided a particularly explosive environment for the interaction of external shocks and imperfect policies.

To make this central argument plausible (proof seems impossible), I will review evidence from six Latin American countries: Argentina, Brazil, Colombia, Mexico-which have the region's largest populations and gross domestic products-and medium-sized Chile and Venezuela. These six countries together represent at least 80 percent of any significant Latin American economic aggregate. The growth performances of the six countries varied before 1981 . Their external circumstances were different, with some of the group being oil importers and others oil exporters. Policy styles ranged from decidedly interventionist to militantly laissez faire. Reliance on external borrowing varied. Clear-eyed hindsight shows that the extent of policy errors was also different from country to country. Yet all six had serious economic difficulties during 1982-83 and faced a weak recovery during 1984 .

I will attempt to imagine how the future looked to these countries in 1980. I will analyze and date the crisis, examining the various external shocks, domestic adjustment policies, and resulting economic performance of the different economies. In an econometric interlude I will scrutinize separately three crucial relations in these economies: the import function, the export function, and the determinants of the real exchange rate.

The paper's last section will focus on financial variables whose performance characterizes the crisis of the early 1980s. A discussion of the contrast between "national" external debt and private external assets will emphasize the asymmetric attitudes that exist toward those two sides of the Latin American balance sheet. One overlooks important policy issues and redistributive effects when both private and public Latin American external debts are lumped together and when private (and sometimes even public) assets abroad are ignored. These considerations indicate that the debt crisis is not just a North-South issue; for several Latin American countries it is also an issue of the distribution of domestic income and wealth. Many observers have marveled at the more-or-less punctual servicing of Latin American debts during the early 1980 s, a performance in sharp contrast with the 1930s; however, "countries" do not decide whether or not to service debt-individual political actors do. The paper addresses the issue of debt servicing with a 
discussion of these actors' perceptions of the costs and benefits of active or passive default. The paper closes with a review of the meager rewards to adjustment during 1982-83, likely future scenarios, and modest policy proposals.

The development crisis in Latin America is forcing a salutary reexamination of the role of the public and private sectors in capital formation and other economic activities; receiving particular attention is the efficiency and welfare consequences of the many functions assumed by public sectors during the last half century. Nevertheless, the 1982-83 crisis was centered predominantly on the balance of payments and on the balance of international indebtedness. The paper will, therefore, focus on variables impinging strongly on foreign exchange flows.

\section{Background to Crisis: Could It Have Been Foreseen?}

This section first sketches the heterogeneous pre-1981 performances, external conditions, and policies of the six countries under study and then identifies from their pre-crisis history the vulnerabilities and excesses that may have led to the troubles of the 1980s. Several serious weaknesses are found, particularly in Argentina and Chile, the two countries most in favor with the international financial community around 1980-81, but I argue that even in those countries, the information available at the time suggested no crisis of the magnitude witnessed during 1982-84.

\section{PRE-CRISIS PERFORMANCE}

A perspective on pre-crisis performance comes from examining trend growth rates for $1960-83$ as well as for two consecutive seven-year periods: the prosperous one from 1966 through 1973 and the troubled one from 1973 through $1980 .{ }^{1}$ Four countries registered impressive or respectable rates of GDP growth for the whole period: Brazil, Colombia,

1. Space limitations preclude the extensive representation of these trends, obtained from the usual semilogarithmic regressions. They were computed from basic data at constant prices obtained from the United Nations Economic Commission for Latin America, which in turn relies on national statistics; and from the International Monetary Fund, International Financial Statistics and Direction of Trade, various issues. Andres Bianchi kindly provided the data available at the U.N. Economic Commission for Latin America. 
Mexico, and Venezuela. The growth rate slowed during the second septennium but remained reasonably fast. (Mexico had a burst of growth averaging 8 percent per year from 1978 through 1981.) Argentina and Chile have grown slowly at least since the late 1920s. Argentina perked up during 1966-73 only to do miserably in the following period; Chile did somewhat better in the 1970s, but its growth was quite unstable. It appears that very fast and very slow growth are associated with instability, both when the six countries are compared for the whole period and when growth rates of a given country are contrasted between the two septennia. With the exceptions of Colombia and Venezuela, there is little evidence that the growth of the 1970s led to significant improvements in income distribution or social harmony; on the contrary, the societies were left with internal divisions not conducive to nimble and resolute domestic responses to external shocks.

Using gross fixed investment and GDP data, one can compute marginal capital-output ratios to obtain a rough index of the productivity of the investment. With three-year averages and investment lagged one year, the ratios are as follows:

$\begin{array}{lcc} & 1961-63 \text { to } & 1971-73 \text { to } \\ 1971-73 & 1979-81 \\ \text { Argentina } & 4.4 & 11.1 \\ \text { Brazil } & 2.9 & 3.3 \\ \text { Chile } & 3.8 & 5.0 \\ \text { Colombia } & 3.1 & 3.3 \\ \text { Mexico } & 2.5 & 3.1 \\ \text { Venezuela } & 4.2 & 7.2\end{array}$

Brazil, Colombia, and Mexico-the fastest growers-had the lowest marginal capital-output ratios, and the ratios increased only slightly from one period to the next. Argentina, Chile, and Venezuela not only had lower investment productivity (which could be due either to supply inefficiencies or to poor management of aggregate demand) throughout the years under study but also experienced a sharp decline in that productivity after 1971-73. For Venezuela, disaggregation into oil and non-oil sectors might yield a better picture for the non-oil sector; nonoil output has grown more than OPEC-restricted petroleum production since the early 1970 s.

The correlation for 1960-83 between the growth of GDP and the growth of the purchasing power of exports is high for our sample of 
countries. ${ }^{2}$ Contrary to widespread assertions, the trend growth of the purchasing power of exports improved in four of the six countries between 1966-73 and 1973-80. It is also noteworthy that Mexican exports measured in current dollars grew faster than those of Korea between 1972-74 and 1979-81.

Coffee and oil prices did well during the 1970s, so there is a sharp difference in the behavior of the terms of trade for Colombia, Mexico, and Venezuela on the one hand and, on the other, those for Argentina, Brazil, and Chile, which declined during 1973-80. In the same period, export volume grew rapidly except for Colombia and Venezuela. Also during 1973-80 Argentina and Chile made impressive gains in export volume; of the six countries, only Mexico showed faster growth in both its terms of trade and exports volume during 1973-80. Since at least the 1960s most Latin American countries show a trend toward geographic diversification of exports away from countries of the Organization for Economic Cooperation and Development (OECD); typically, that trend has been accompanied by the diversification of commodities exported. The geographic diversification of exports accelerated markedly during 1973-80 in Argentina, Chile, and Venezuela, advanced less in Brazil, and was reversed in Colombia by the coffee bonanza; Mexico shows no significant trend in diversification.

Philosophies guiding economic policy in our sample of countries were as heterogeneous during the 1970 s as were performance and external circumstances. At one extreme, Chile moved toward free trade, a balanced budget, and laissez faire; at the other, Brazil remained wedded to growth-oriented military statism, which had shown spectacular results from 1966 through 1973. Brazil and Mexico pursued external borrowing far more vigorously than prudent Colombia. Currency convertibility and capital movements were freer in Mexico and Venezuela than in Sweden but were severely limited in Colombia and Brazil. Import controls were dismantled in Argentina and Chile while they remained crucial elements in the protectionist arsenal of Brazil and even Mexico; amazing differ-

2. The purchasing power of merchandise exports is defined as the dollar value of exports deflated by dollar import prices or, more exactly, import unit values. In other words, it is equal to the terms of trade multiplied by export volume. I conjecture that the purchasing power of exports data, obtained from the U.N. Economic Commission for Latin America, are more reliable than data giving separately the terms of trade and export volume, which appear to have compensating errors. 
ences in apparent income elasticities in the demand for imports appear in our sample during 1973-80.

\section{INVESTMENT PERFORMANCE}

With this sketchy background in hand, place yourself at the end of 1980 (or even mid-1981) and try to detect signs of serious trouble ahead. There were indeed some troublesome signs. We have seen that the marginal capital-output ratios for Argentina, Chile, and Venezuela showed low investment productivity. There was concern about some investment projects undertaken by Latin American countries: expansions in steel, petrochemicals, and aluminum alarmed those connected with those activities in industrialized countries. The Brazilian opposition muttered about "pharaonic projects" in hydroelectric dams, atomic energy and gasohol facilities, railroads, subways, and other infrastructure. The Chilean opposition whispered that all those shopping centers in fashionable areas of Santiago could never generate the foreign exchange needed to service their external debts. Others focused on perceived imbalances between private and public investments and related imbalances between trade and nontrade sectors. Investments in nontrade sectors were often financed by external debt, raising questions about the capacity to transform either their domestic earnings or the tax revenues they generate into dollars needed for debt servicing. In both Mexico and Venezuela, where such data are available, oil booms led to a faster growth of public than of private investments. Between 1972-73 and 1979-80 Mexican public investment grew at an average annual rate of 11.1 percent while private investment expanded at a 6.7 percent rate. The corresponding Venezuelan figures were 10.6 and 5.0. ${ }^{3}$ Arms purchases and capital formation undertaken by the military, which often controlled major public enterprises, made many civilians uneasy. Most of these doubts were dismissed as politically motivated or as motivated among foreigners by fears of competition. Indeed, there were few documented criticisms casting serious doubts on the ex ante social profitability of specific projects; even fewer criticisms documented at a disaggregated level a decline in investment efficiency between 1966-73 and 1973-80.

3. Sources described in note 1 . 


\section{REAL EXCHANGE RATES}

The Argentine real exchange rate with the U.S. dollar was unstable around an appreciating trend during 1973-80 even as the terms of trade fell, and the government announced plans to liberalize imports. For Brazil the 1973-80 pace of real depreciation with respect to the U.S. dollar seemed small given the deterioration in its terms of trade; Brazil moved only slowly to adjust both its real exchange rate and its domestic oil prices to the new international relative prices. During 1973-80 Chile not only faced a severe deterioration in its terms of trade but also took a leap toward free trade, with nearly all tariffs down to 10 percent by 1980 ; it experienced only a weak and unsteady depreciation trend over this period. Indeed, real dollar exchange rates became more unsteady during 1973-80 than they had been during 1966-73 for all the countries except Venezuela, with the instability particularly high for Argentina and Chile. ${ }^{4}$

The behavior of real exchange rates during the late 1970s deserves a closer look. Table 1 presents those rates defined with respect both to the U.S. dollar and to a basket of currencies; this table also includes data for the early 1980s. Argentina and Chile adopted policies of preannouncing nominal exchange rates with respect to the U.S. dollar in the hope of rapidly reducing inflation; inflation was reduced but not fast enough. In Argentina there was a remarkable real appreciation between 1977 and 1980; the real exchange rates for 1979-81 were more overvalued than during the first and second Peronist administrations. In Chile a less sensational appreciation trend occurred between 1978 and 1981. The Brazilian crawling peg avoided a significant appreciation during 197579 , while that of Colombia failed to do so under pressure from the coffee bonanza. In 1976 Mexico abandoned its fixed nominal exchange rate with respect to the dollar, held steady since 1954, to achieve real depreciations in 1976 and 1977, only to let the oil boom lead to real appreciation between 1977 and 1982 . Venezuela held its nominal dollar rate steady with the help of abundant foreign exchange reserves and managed to keep its domestic inflation close to that of the United States

4. The assertions regarding the instability of real dollar exchange rates, like those made earlier regarding the instability of growth rates, are based on the examination of mean square errors for the relevant trend regression. 
Table 1. Real Exchange Rates, 1975-83 ${ }^{\text {a }}$

Local currency per U.S. dollar or per currency basket (index, $1980=100$ )

\begin{tabular}{cccccccccc}
\hline $\begin{array}{c}\text { Country } \\
\text { and } \\
\text { exchange } \\
\text { measure }\end{array}$ & 1975 & 1976 & 1977 & 1978 & 1979 & 1980 & 1981 & 1982 & 1983 \\
\hline $\begin{array}{c}\text { Argentina } \\
\text { Dollar }\end{array}$ & 280 & 208 & 234 & 179 & 127 & 100 & 129 & 305 & 288 \\
$\quad$ Basket & 194 & 128 & 165 & 149 & 112 & 100 & 131 & 163 & 150 \\
$\begin{array}{c}\text { Brazil } \\
\text { Dollar }\end{array}$ & 79 & 78 & 76 & 76 & 82 & 100 & 95 & 98 & 134 \\
Basket & 76 & 74 & 74 & 78 & 88 & 100 & 85 & 82 & 95 \\
$\begin{array}{c}\text { Chile } \\
\text { Dollar }\end{array}$ & 124 & 112 & 103 & 116 & 114 & 100 & 92 & 116 & 146 \\
Basket & 140 & 120 & 99 & 111 & 112 & 100 & 83 & 94 & 110 \\
$\begin{array}{c}\text { Colombia } \\
\text { Dollar }\end{array}$ & 127 & 125 & 106 & 103 & 100 & 100 & 100 & 100 & 106 \\
Basket & 119 & 113 & 102 & 103 & 99 & 100 & 94 & 88 & 89 \\
$\begin{array}{c}\text { Mexico } \\
\text { Dollar }\end{array}$ & 93 & 105 & 127 & 117 & 111 & 100 & 92 & 138 & 154 \\
Basket & 103 & 109 & 120 & 115 & 107 & 100 & 91 & 132 & 141 \\
$\begin{array}{c}\text { Venezuela } \\
\text { Dollar }\end{array}$ & 111 & 109 & 108 & 108 & 107 & 100 & 95 & 92 & 90 \\
Basket & 115 & 111 & 105 & 107 & 108 & 100 & 92 & 85 & 80 \\
\hline
\end{tabular}

Source: The real exchange rates with respect to currency baskets for 1975-80, United Nations Economic Commission for Latin America, Economic Survey of Latin America, 1981, Statistical Appendix (Santiago, Chile, 1983), and forthcoming issues for preliminary data for 1981-83. The real dollar exchange rate was calculated with data from the International Monetary Fund, International Financial Statistics, various issues, line rf for nominal rates and line 64 for inflation.

a. The real rates with respect to currency baskets were calculated as a weighted average of the real exchange rate of each country with its main trading partners. The weights used were the importance of the trading partners in the import and export trade. Inflation was measured by wholesale prices except for Chile, where consumer prices were used as adjusted for 1975-78 by René Cortázar and Jorge Marshall. The real rates with respect to the dollar were defined as the average yearly nominal rate, corrected by inflation as measured by consumer prices, in each country and in the United States.

at least until 1979. Both the real appreciations that had occurred by 1980 and the practice of pegging to the U.S. dollar, especially when done in a preannounced fashion, were to increase the vulnerability of these economies to the events of the early 1980s. The international reserves that backed exchange rate commitments were to prove evanescent, especially in countries without exchange controls.

\section{DEB T}

By 1980 debt indicators presented a mixed but not necessarily an alarming picture. Consider debt first as a percent of exports (table 2). 
Table 2. Principal Debt Ratios, Selected Years, 1973-80a

Percent

\begin{tabular}{lccrr}
\hline Country & 1973 & 1975 & 1979 & 1980 \\
\hline \multicolumn{5}{c}{ Debt to total exports } \\
Argentina & 74.3 & 87.0 & 86.7 & 90.9 \\
Brazil & 107.0 & 139.0 & 197.3 & 169.7 \\
Chile & 191.7 & 202.6 & 101.4 & 75.2 \\
Colombia & 121.8 & 106.0 & 68.0 & 69.4 \\
Mexico & 115.4 & 181.3 & 182.7 & 135.9 \\
Venezuela & 29.2 & 12.5 & 60.1 & 48.9 \\
& Interest payments to total & exports & \\
Argentina & 5.3 & 7.4 & 5.7 & 7.5 \\
Brazil & 5.5 & 8.5 & 16.2 & 18.0 \\
Chile & 2.5 & 8.5 & 7.5 & 7.7 \\
Colombia & 4.9 & 5.1 & 4.6 & 4.8 \\
Mexico & 7.1 & 13.1 & 17.8 & 15.5 \\
Venezuela & 1.9 & 1.0 & 4.0 & 5.5 \\
& International reserves & to & debt & \\
Argentina & 57.4 & 27.2 & 135.2 & 91.3 \\
Brazil & 86.4 & 30.1 & 27.7 & 17.4 \\
Chile & 9.8 & 6.4 & 56.5 & 87.4 \\
Colombia & 28.9 & 26.7 & 149.4 & 159.1 \\
Mexico & 30.1 & 16.4 & 10.6 & 12.4 \\
Venezuela & 207.3 & 790.4 & 134.5 & 122.9 \\
\hline
\end{tabular}

Source: World Bank, World Debt Tables, 1983-84 (Washington, D.C., 1984).

a. Debt is defined as external debt that has an original or extended maturity of more than one year; it comprises public and publicly guaranteed obligations, outstanding and disbursed.

For Chile and Colombia that ratio in 1980 was lower than in 1973. Except for Brazil and Mexico the ratio appeared quite comfortable in 1980. Even for Brazil and Mexico the ratio had declined between 1979 and 1980; for Mexico there had also been a decline between 1975 and 1980 .

The percent of export earnings taken up by interest payments, also presented in table 2, had risen since 1973, but its absolute level, even for Brazil and Mexico, was far from extravagant. Last, international reserves were either higher than or almost as high as the external debt in Argentina, Chile, Colombia, and Venezuela. In Brazil and Mexico this indicator had deteriorated since 1973, so that the growth of debt net of reserves since the early 1970 s could have been regarded as unsustainable. As "collateral" for Mexico's external debt, however, oil deposits in 1980-81 appeared as good as international reserves.

A Cassandra would have been right about debt in 1980, but she would have had to rely on nonquantitative, metaphysical insights. As early as 
1979, perhaps, a case could have been made by, say, a prudent Brazilian planner to slow down debt and GNP growth but without precipitating a major depression. ${ }^{5}$ In all other countries, 1980 debt indicators and aggregate measures of creditworthiness did not look significantly worse than they did in 1973. During 1980 one could have recalled that both borrowers and capital markets negotiated the 1974-75 recession successfully.

It may be argued that only public and publicly guaranteed debt is considered in table 2 and that unguaranteed private debt was already getting out of hand by 1980 . This may be true ex post, but it is ahistorical. The explicit and implicit rules of the game of 1980 were that private agents were on their own when lending or borrowing, unless governments explicitly guaranteed their debt. Listen to Walter Robichek, then director of the Western Hemisphere Department of the International Monetary Fund, giving his personal views in Santiago, Chile, in 1980:

In the case of the private sector, I would argue that the difference between domestic and foreign debt is not significant-barring governmental interference with the transfer of service payments or other clearly inappropriate public policies-if it exists at all. The exchange risks associated with foreign borrowing are presumably taken into account as are the other risks associated with borrowing, whether it be from domestic or foreign sources....

There is understandably greater concern with certain forms of foreign savings flows to a developing country than with others. These flows can be grouped into three broad categories, namely, flows into the private sector without official guarantee, the same flows with official guarantee, and flows into the public sector. The first category holds out the strongest presumption that the foreign savings will be profitably invested and, hence, this category should pose the least potential debt servicing problems. Bringing an official guarantee into play diminishes somewhat the force of the discipline that tends to ensure that foreign savings are profitably invested, although it minimizes the risk of governmental interference with the transfer of service payments. Overborrowing in both of these categories is, therefore, very unlikely, provided official guarantees are given on a selective basis. With this proviso, it is not necessary to distinguish in the context of this paper between the different forms which the flow of foreign savings into the private sector can take. ${ }^{6}$

5. The case in fact was made within Brazil. See Carlos F. Diaz-Alejandro, "Some Aspects of the 1982-83 Brazilian Payments Crisis," BPEA, 2:1983, pp. 515-42. But see also comments by Richard N. Cooper, arguing that in 1979 that approach would have been excessively conservative (BPEA, 2:1983, pp. 543-47).

6. E. Walter Robichek, "Some Reflections About External Public Debt Management," in Banco Central de Chile, Alternativas de Políticas Financieras en Economías Pequeñas 
Even during 1980 there was scattered concern that external debt, whether public or private, had financed consumption, not investment. But many serious analysts concluded that the growth of debt in Latin American and other less developed countries reflected not unsustainable consumption but increased investment, so that repayment problems were not likely. Indeed, the international financial market appeared to recognize with creditworthiness and low spreads the efforts made in capital formation, presumably because both the level and the allocation of investment appeared sound. ${ }^{7}$

Another concern during 1980-81 could have been that the public debt was financing not bad investment projects nor unsustainable consumption but private capital flight. (It is moot whether capital flight is worse, from the viewpoint of national welfare, than financing arms purchases and other wasteful absorption.) Were public and publicly guaranteed borrowings exceeding current account deficits plus reserve accumulation before 1982? Table 3 presents thumbnail summaries of accumulated current account deficits covering the period from 1974 through 1981. This summary hides the fact that Brazil and Mexico steadily maintained large deficits throughout that period and that the bulk of the accumulated deficits for Argentina and Chile occurred from 1979 through 1981. Table 3 divides the current account deficit into net factor payments plus the deficit in the rest of the current account. It may be seen that for the whole of 1974 through 1981 Argentina, Colombia, and Venezuela had surpluses in the current account excluding factor payments; Venezuela with its then-monumental reserves even had a surplus on net factor payments and must have benefited from the rise in interest rates during 1980-81. Only Brazil, Chile, and Mexico obtained real resource inflows, on balance, during the heyday of the international capital market.

There is little evidence in table 3 showing that public borrowing was financing massive net private capital flight. For Argentina, Mexico, and Venezuela, for which the World Bank Debt Tables do not give data for purely private debt, the last line in table 3 ("missing") is small even

\footnotetext{
y Abiertas al Exterior; Estudios Monetarios VII (Santiago, Chile, December 1981), pp. 171-72. Interestingly, the refrain of "too much debt, too little equity," which has become quite popular since 1982, is here rejected with a sweeping Modigliani-Miller assertion.

7. See for example Jeffrey D. Sachs, "The Current Account and Macroeconomic Adjustment in the 1970s," BPEA, 1:1981, especially pp. 243-47; and Robert Solomon, “The Debt of Developing Countries: Another Look," BPEA, 2:1981, pp. 593-607.
} 


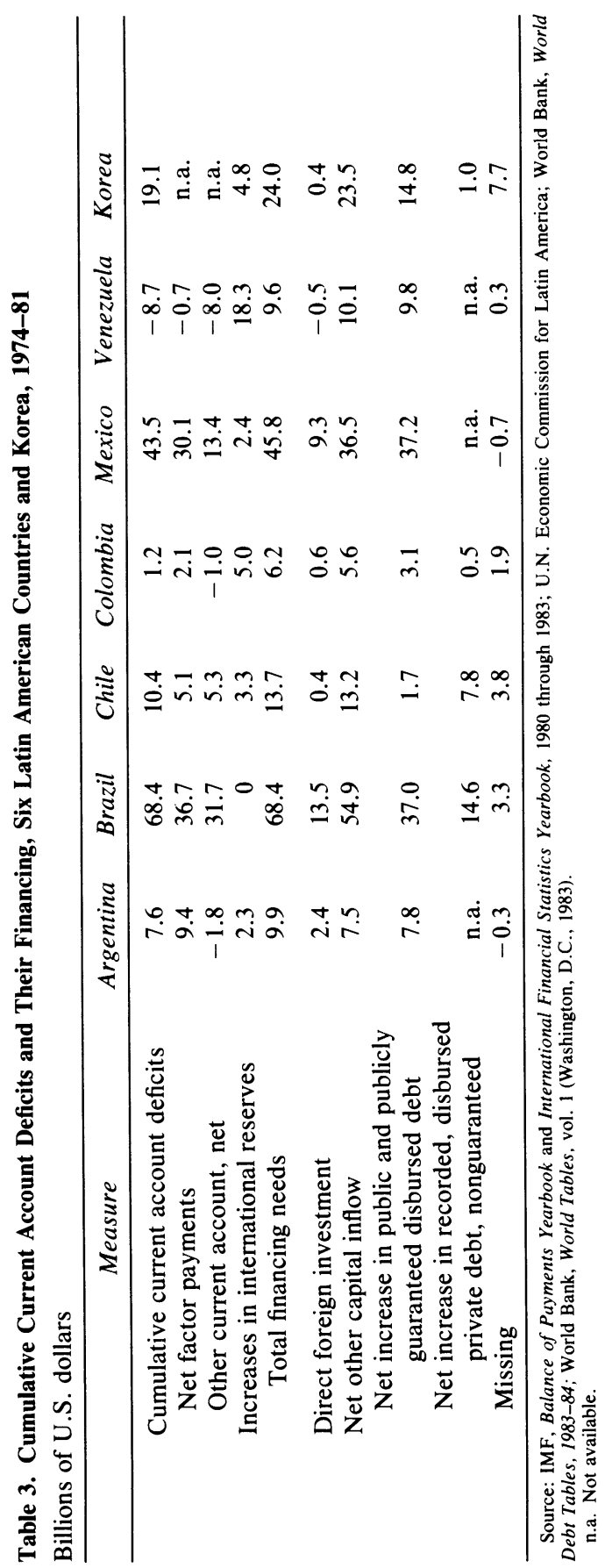


when negative; this suggests that net increases in private assets abroad were close to net increases in external private liabilities. ("Missing," like any residual, is also picking up all sorts of measurement errors.) For Brazil, Chile, and Colombia, for which data on purely private debt are available and indicate recorded inflows, the "missing" line in table 3 is positive, suggesting further net private capital inflows. It could be argued that overinvoicing of imports and underinvoicing of exports exaggerate current account deficits, thus reducing the residual in table 3; on the other hand, some government imports, especially armaments, may not be included in official data.

Table 3 also shows that Korean virtue must be sought elsewhere than in emphasizing equity rather than debt in external financing; Brazil shows far greater reliance on direct foreign investment, in relative and absolute terms, than Korea or even Chile, whose regulations on direct foreign investors during the years shown were not particularly punitive. Relative to its financing needs, Chile registers an enormous net nonequity capital inflow on private nonguaranteed account.

Both Argentina and Chile stimulated an unsound expansion of domestic financial intermediation during the late 1970s; banks and financial conglomerates felt insured by governments, de facto if not de jure, and engaged in extravagant practices, including massive borrowing abroad from foreign banks sharing the enthusiasm for financial deregulation and the end of financial repression. ${ }^{8}$

It is true that in 1980-81 governments and public enterprises in several countries rapidly increased their spending. Mexico and Venezuela appeared to believe together with most international experts that real oil prices would continue upward and finance all sorts of development projects. Militarists in authority in Argentina and Chile armed themselves for war (even as the "rational" technocrats of those regimes proudly stamped out inefficiencies in the civil sphere).

Last, even observers who doubted the stability and perfection of international capital markets as they operated in 1980-81 reasoned that if a major international economic crisis were to break out, indebted Latin

8. For more on this story see Carlos F. Diaz-Alejandro, "Good-Bye Financial Repression, Hello Financial Crash," Journal of Development Economics, forthcoming. Financial intermediaries were more closely supervised in the other countries, but excesses and supervisory failures were also seen there, even in Colombia. 
American countries could use their bargaining power to soften the debt burden, very much as they had done during the 1930s. ${ }^{9}$

\section{SUMMARY：THE VIEW IN 1980-81}

By 1980-81 most countries under study faced the need for adjustment and reform policies even under the assumption that the international economy would behave during the rest of the 1980 s on average as it did during the 1970s. Overvalued exchange rates, brittle domestic financial systems, and lax budgets, in addition to the Sisyphus-like struggle with inflation, called for urgent action. Before the 1970s international investors had too little Latin American paper in their portfolios; by the late 1970s this situation had been largely corrected. After such a one-time stock adjustment, the capital inflows which could have been expected for the 1980s were bound to be smaller than those seen during the 1970s, at least for Brazil and Mexico. It could also have been expected that higher spreads and shorter maturities would be needed to induce lenders to assume the greater risks foreseen for the $1980 \mathrm{~s} .{ }^{10}$

Substantial adjustments and reforms were thus needed in 1980 and 1981; but nothing in the situation called for traumatic depressions. In the case of Brazil some adjustment was already under way certainly by 1981 . The inevitable substantial real devaluations in Argentina and Chile were bound to cause significant recessions and financial stress, but as in the previous economic history of those countries, a "go" stage was to be expected shortly after a sharp "stop." And very few observers in 1981 could have forecast that Colombia, Mexico, and Venezuela would grow

9. See p. 35, the last paragraph, in Edmar L. Bacha and Carlos F. Diaz-Alejandro, International Financial Intermediation: A Long and Tropical View, Essays in International Finance 147 (Princeton University, International Finance Section, May 1982). That paragraph was written by me.

10. This was argued by Paul A. Volcker in March 1980. In the same speech he also stated: "The impression I get from the data that $I$ have reviewed is that the recycling process has not yet pushed exposure of either borrowers or lenders to an unreasonable or unsustainable point in the aggregate, especially for American banks whose share in total bank lending to non-oil developing countries in recent years has declined and whose share of claims on these countries in total assets has also declined. But problem cases exist now and will no doubt continue to show up." Paul A. Volcker, "The Recycling Problem Revisited," Challenge, vol. 23 (July/August 1980), p. 13. Ironically, banks searching for shorter maturities to cover against the increased risks of the 1980s have ended up with quasi-perpetual loans in their books. 
during the rest of the 1980s at rates significantly below their postwar trend expansion. One may note that while Brazil, Colombia, Mexico, and Venezuela were keeping at arms' length from the IMF, Argentina and Chile appeared to have excellent relations with that institution, which presumably advised them on exchange rates and other policies. Indeed, eminent international financiers and economists often presented Argentina and Chile during 1980 and 1981 as examples of sound economic management. Advice to these and other third world nations became widespread (and lucrative) during those years and included some of the best known New York investment bankers. ${ }^{11}$ Few have credibly claimed to have warned the countries of the impending crisis.

\section{The Crisis}

I turn now to the crisis itself, first describing the external shocks received by Latin American countries during the early 1980s. Then, after examining adjustment policies undertaken by the six countries to deal with the crisis, I review the dismal economic performance that resulted.

THE EXTERNAL SHOCKS

Table 4 summarizes the key developments surrounding the crisis that emerged. Until 1981-82, new bank loans far exceeded net interest payments in the countries under study. Only a superficial observer could have labeled this situation a "Ponzi scheme," as some have done recently. As already noted, during the 1970s a stock adjustment had occurred in international portfolios, making up for about 40 years of insignificant inflows of private nonequity capital into Latin America. From 1979 through 1981 new loans reached more than half the value of exports in Argentina, Chile, and Mexico. Even fuel-short Brazil and Chile had comfortable amounts of foreign exchange left over after paying for interest and oil. That residual (loans plus exports minus oil minus interest) collapsed dramatically between 1981 and 1982 in Argentina,

11. Ann Crittenden, "Consultants to the Third World: Three Investment Banks Join to Sell Advice," New York Times, September 23, 1980, p. D1. 
Table 4. Loans, Exports, Interest, and Oil Imports, 1979-83a

Billions of U.S. dollars

\begin{tabular}{|c|c|c|c|c|c|}
\hline Country and measure & 1979 & 1980 & 1981 & 1982 & 1983 \\
\hline \multicolumn{6}{|l|}{ Argentina } \\
\hline Net new bank loans & 6.35 & 5.91 & 4.00 & -0.77 & 1.19 \\
\hline Merchandise exports, f.o.b. & 7.81 & 8.02 & 9.14 & 7.63 & 7.71 \\
\hline Subtotal & 14.16 & 13.93 & 13.14 & 6.83 & 8.90 \\
\hline All interest payments, net & 0.49 & 0.95 & 2.96 & 4.40 & 4.98 \\
\hline Oil imports & 0.35 & 0.53 & 0.30 & 0.16 & 0.16 \\
\hline Residual & 13.32 & 12.45 & 9.88 & 2.27 & 3.76 \\
\hline \multicolumn{6}{|l|}{ Brazil } \\
\hline Net new bank loans & 5.08 & 6.51 & 6.29 & 6.48 & 1.38 \\
\hline Merchandise exports, f.o.b. & 15.24 & 20.13 & 23.28 & 20.17 & 21.90 \\
\hline Subtotal & 20.32 & 26.64 & 29.57 & 26.65 & 23.28 \\
\hline All interest payments, net & 4.10 & 6.31 & 9.16 & 11.35 & 9.56 \\
\hline Oil imports & 6.44 & 9.85 & 11.01 & 10.21 & 7.90 \\
\hline Residual & 9.78 & 10.48 & 9.40 & 5.09 & 5.82 \\
\hline \multicolumn{6}{|l|}{ Chile } \\
\hline Net new bank loans & 1.78 & 2.17 & 2.91 & 0.86 & 0.52 \\
\hline Merchandise exports, f.o.b. & 3.83 & 4.71 & 3.84 & 3.71 & 3.83 \\
\hline Subtotal & 5.61 & 6.88 & 6.75 & 4.57 & 4.35 \\
\hline All interest payments, net & 0.63 & 0.85 & 1.34 & 1.79 & 1.63 \\
\hline Oil imports & 0.79 & 0.73 & 0.60 & 0.25 & 0.19 \\
\hline Residual & 4.19 & 5.30 & 4.81 & 2.53 & 2.53 \\
\hline \multicolumn{6}{|l|}{ Colombia } \\
\hline Net new bank loans & 1.40 & 0.80 & 0.61 & 0.67 & 0.39 \\
\hline Merchandise exports, f.o.b. & 3.51 & 4.06 & 3.22 & 3.55 & 3.02 \\
\hline Subtotal & 4.91 & 4.86 & 3.83 & 4.22 & 3.41 \\
\hline All interest payments, net & 0.21 & 0.16 & 0.30 & 0.72 & 0.62 \\
\hline Oil imports & 0.30 & 0.52 & 0.57 & 0.62 & 0.49 \\
\hline Residual & 4.40 & 4.18 & 2.96 & 2.88 & 2.30 \\
\hline \multicolumn{6}{|l|}{ Mexico } \\
\hline Net new bank loans & 7.49 & 10.24 & 14.49 & 3.45 & 3.95 \\
\hline Merchandise exports, f.o.b. & 9.30 & 16.07 & 19.94 & 21.23 & 21.40 \\
\hline Subtotal & 16.79 & 26.31 & 34.43 & 24.68 & 25.35 \\
\hline All interest payments, net & 3.01 & 4.45 & 7.00 & 9.63 & 8.80 \\
\hline Residual & 13.78 & 21.86 & 27.43 & 15.05 & 16.55 \\
\hline \multicolumn{6}{|l|}{ Venezuela } \\
\hline Net new bank loans & 5.68 & 2.80 & 0.97 & 0.37 & -0.65 \\
\hline Merchandise exports, f.o.b. & 14.16 & 19.05 & 19.96 & 16.33 & 13.80 \\
\hline Subtotal & 19.84 & 21.85 & 20.93 & 16.70 & 13.15 \\
\hline All interest payments, net & -0.31 & -0.65 & -0.92 & 1.13 & 1.72 \\
\hline Residual & 20.15 & 22.50 & 21.85 & 15.57 & 11.43 \\
\hline
\end{tabular}

Source: Net new loans, table 5, Bank for International Settlements, International Banking Statistics, 1973-1983 (Basel, April 1984). Merchandise exports free on board and net interest payments, U.N. Economic Commission for Latin America, Economic Survey for Latin America 1983 (Santiago, Chile, forthcoming). Oil imports, Inter-American Development Bank, External Debt and Economic Development in Latin America: Background and Prospects (Washington, D.C., January 1984), p. 43.

a. Net new loans, including "involuntary" or "concerted" loans, are the changes in end-of-year external positions (assets) of banks in the BIS reporting area plus some offshore branches of U.S. banks. 
Brazil, Chile, and Mexico; in Colombia and Argentina a severe contraction had already occurred during 1981.

In Argentina and Chile, the decline between 1981 and 1982 in the inflows of loans, including loans of an "involuntary" nature, exceeded the fall in exports. In these and other countries, the pro-cyclical swing in loans turned an already serious export decline into the worst crisis since the early 1930s for Latin America. During 1982 and 1983 sharply increased interest outflows exceeded net new loans in all countries under study. In contrast with 1974-75, the external real shock was magnified by a financial shock; the latter may be more durable and harmful to Latin American economies than the former.

It is worthwhile to go beyond these simple facts to examine in greater detail the timing and other characteristics of the decline in private capital inflows and the purchasing power of exports. The financial shock was already visible in some countries during the first half of 1982. The Polish debt crisis became apparent during the second half of 1981 and the war over the Malvinas/Falkland Islands started in April 1982. Net loans to Argentina turned negative during that fateful half even as lending to Mexico expanded dramatically. ${ }^{12}$ During the second half of 1981 and the first half of 1982 Mexico received $\$ 17$ billion in new loans; in that period the Mexican president mocked those technocrats who had warned him about the limits to foreign borrowing. The same year also witnessed record lending to Brazil.

Even with "involuntary" or "concerted" lending, the second half of 1982 through the first half of 1983 witnessed an abrupt collapse in net inflows except in the case of Colombia. Those yearly inflows became negative for Chile, Mexico, and Venezuela. Interestingly, loans to Chile expanded significantly during the second half of 1983, after sharp cuts during the first half; these data are consistent with rumors of banks applying pressure on Chile to guarantee ex post the external debt undertaken by private Chilean financial intermediaries and with the Chilean cave-in to this pressure around mid-1983.

The decline in the absolute dollar value of exports preceded the decline in loans, except in Argentina, where both declined during the first half of 1982. As shown in table 5, Chilean and Colombian exports had turned down by the first half of 1981; those of Venezuela by the second half of 1981; those of Brazil and Mexico by the first half of 1982.

12. Data on net new loans obtained as in table 4 . 
Table 5. Exports and Loans, 1981-83

Percent change from same period in previous year

\begin{tabular}{|c|c|c|c|c|c|c|}
\hline \multirow[b]{2}{*}{$\begin{array}{c}\text { Country and } \\
\text { measure }\end{array}$} & \multicolumn{2}{|c|}{1981} & \multicolumn{2}{|c|}{1982} & \multicolumn{2}{|c|}{1983} \\
\hline & $\begin{array}{l}\text { First } \\
\text { half }\end{array}$ & $\begin{array}{c}\text { Second } \\
\text { half }\end{array}$ & $\begin{array}{l}\text { First } \\
\text { half }\end{array}$ & $\begin{array}{c}\text { Second } \\
\text { half }\end{array}$ & $\begin{array}{l}\text { First } \\
\text { half }\end{array}$ & $\begin{array}{l}\text { Second } \\
\text { half }\end{array}$ \\
\hline \multicolumn{7}{|l|}{ Argentina } \\
\hline Exports & 21 & 7 & -7 & -28 & -11 & 18 \\
\hline Exports plus loans & 2 & -14 & -38 & -60 & 8 & 72 \\
\hline \multicolumn{7}{|l|}{ Brazil } \\
\hline Exports & 18 & 14 & -10 & -17 & 6 & 11 \\
\hline Exports plus loans & 0 & 20 & 6 & -21 & -9 & -16 \\
\hline \multicolumn{7}{|l|}{ Chile } \\
\hline Exports & -18 & -15 & -4 & -6 & -1 & 2 \\
\hline Exports plus loans & 5 & -6 & -7 & -55 & -50 & 80 \\
\hline \multicolumn{7}{|l|}{ Colombia } \\
\hline Exports & -28 & -23 & 9 & 3 & -9 & 4 \\
\hline Exports plus loans & -33 & -19 & 15 & 2 & 7 & -23 \\
\hline \multicolumn{7}{|l|}{ Mexico } \\
\hline Exports & 41 & 6 & -12 & 30 & 9 & -5 \\
\hline Exports plus loans & 29 & 31 & 8 & -55 & -25 & 54 \\
\hline \multicolumn{7}{|l|}{ Venezuela } \\
\hline Exports & 23 & -1 & -29 & -13 & -3 & -14 \\
\hline Exports plus loans & 16 & -10 & -25 & -21 & -13 & -17 \\
\hline
\end{tabular}

Source: Exports refer to merchandise exports, line 70.d, IMF, International Financial Statistics, various issues. Venezuela, line 70; exports in bolivares translated into U.S. dollars at 4.29 bolivares per U.S. dollar. Mexico, line 77.aad through 1982; 1983, line 70 (exports in pesos) and line rf (average dollar exchange rate). Loans, see notes to table 4.

Countercyclical lending was short lived or weak; the absolute value of loans plus exports had turned down markedly by the second half of 1981 for Argentina, Chile, Colombia, and Venezuela. Brazil and Mexico escaped that decline until the second half of 1982; for Mexico it came with a vengeance.

One important factor behind the export troubles of 1981-83 was the decline in the terms of trade, which all six countries experienced to some degree and which for some countries approached the declines suffered during the early 1930s. The Brazilian terms of trade began to fall in 1979 and dropped further every year thereafter, for a total decline of 38.5 percent by 1983 (table 6). The terms of trade for both Chile and Colombia declined by about 25 percent over the $1979-83$ period. For Mexico and Venezuela the 1981-83 terms of trade deteriorations did not offset the gains obtained in 1979 and 1980. 
Table 6. Foreign Trade Indicators, 1979-83 ${ }^{a}$

Percent

\begin{tabular}{|c|c|c|c|c|c|c|}
\hline \multirow[b]{2}{*}{ Country } & \multicolumn{5}{|c|}{ Change from previous year } & \multirow{2}{*}{$\begin{array}{c}\text { Cumulative } \\
\text { change, } \\
1978-83\end{array}$} \\
\hline & 1979 & 1980 & 1981 & 1982 & 1983 & \\
\hline \multicolumn{7}{|c|}{ Terms of trade } \\
\hline Argentina & 1.5 & 16.2 & -5.4 & -7.7 & -3.3 & -0.5 \\
\hline Brazil & -8.8 & -15.6 & -16.8 & -3.7 & -0.2 & -38.5 \\
\hline Chile & 7.2 & -8.2 & -21.2 & -10.4 & 7.5 & -25.3 \\
\hline Colombia & -13.7 & -2.5 & -22.6 & 13.5 & 2.2 & -24.5 \\
\hline Mexico & 11.7 & 24.0 & -1.2 & -17.9 & -3.7 & 8.3 \\
\hline Venezuela & 29.6 & 27.1 & -0.8 & 0.1 & -7.4 & 51.4 \\
\hline \multicolumn{7}{|c|}{ Export volume } \\
\hline Argentina & -1.2 & -12.5 & 16.8 & -5.6 & 9.6 & 4.4 \\
\hline Brazil & 12.0 & 22.3 & 25.0 & -6.6 & 15.4 & 84.4 \\
\hline Chile & 19.1 & 9.1 & -3.8 & 16.1 & 3.4 & 50.1 \\
\hline Colombia & 18.7 & -1.0 & -3.8 & 1.2 & -11.4 & 1.5 \\
\hline Mexico & 17.6 & 23.6 & 18.8 & 22.4 & 12.6 & 137.7 \\
\hline Venezuela & 11.8 & -8.4 & -5.4 & -13.8 & -4.0 & -19.8 \\
\hline \multicolumn{7}{|c|}{ Purchasing power of exports } \\
\hline Argentina & 0.2 & 1.5 & 10.6 & -12.9 & 6.0 & 3.8 \\
\hline Brazil & 2.2 & 3.2 & 4.0 & -10.2 & 15.3 & 13.6 \\
\hline Chile & 27.8 & 0.1 & -24.1 & 3.9 & 11.2 & 12.1 \\
\hline Colombia & 2.5 & -3.5 & -25.5 & 14.9 & -9.6 & -23.4 \\
\hline Mexico & 31.3 & 53.3 & 17.3 & 0.6 & 8.4 & 157.4 \\
\hline Venezuela & 44.8 & 16.4 & -6.2 & -13.8 & -11.1 & 21.3 \\
\hline
\end{tabular}

Source: U.N. Economic Commission for Latin America, Economic Survey of Latin America, 1983.

a. Terms of trade are defined as U.S. dollar prices for merchandise exports f.o.b. divided by dollar prices for merchandise imports valued at cost, insurance, and freight. Export volume covers merchandise exports only.

Export volume did remarkably well during 1982-83 given external circumstances, particularly in Chile, Mexico, and even Brazil. These three countries have expanded export volume impressively since 1978. Venezuela followed OPEC volume restrictions, while Colombia suffered not only from the international recession and the end of the coffee bonanza but also from the collapse of the oil boom in neighboring Ecuador and Venezuela, countries separated from Colombia by porous borders.

Data on export volume show that debt-ridden countries are making significant efforts to carry out the real transfer of at least interest costs. The data also hint that this transfer is partly frustrated by the worsening terms of trade, a worsening which could be endogenous to some degree. By 1983 sharp real devaluations in most Latin American countries, combined with domestic recessions, led to a vigorous export push; with 
many countries engaged in the same efforts, the terms of trade were bound to suffer. While hurting the transfer process, this phenomenon helped the industrialized countries in their fight against inflation by contributing dirt-cheap supplies of primary products and simple manufactures. ${ }^{13}$

The 1981-83 decline in export values was accompanied by a significant reversal of the postwar trend toward diversification in the destination of Latin American exports. With few exceptions, there has been a remarkable collapse of exports to other Latin American countries and to OPEC. Latin American and third world economic integration was revealed to be a thin reed on which to lean in a time of crisis. For most countries, the United States has become the only major expanding market; European and Japanese stagnation or protectionism is apparent in Latin American export data. ${ }^{14}$

Nominal interest rates on foreign loans, which were higher than expected, are known to explain the lion's share of the increase since 1979 in net interest payments, shown in table $4 .{ }^{15}$ Less well known is the fact that when translated into real terms using price indexes relevant for Latin America, the rates on foreign loans reach extraordinary levels. Since 1980, nominal dollar price indexes for Latin American exports and imports have declined. For the whole region, dollar export and import price (unit-value) indexes used by the United Nations Economic Commission for Latin America had the following average annual percentage rates of change:

Dollar prices of exports

Dollar prices of imports

Average dollar prices for exports and imports Addendum

U.S. wholesale prices

$$
\begin{gathered}
1965-66 \text { to } \\
1972-73
\end{gathered}
$$

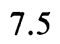

4.2

6.0

3.7

$$
\begin{gathered}
1972-73 \text { to } \\
1979-80
\end{gathered}
$$

8.6

15.6

10.3

$$
\begin{gathered}
1979-80 \text { to } \\
1982-83
\end{gathered}
$$$$
-1.1
$$

13. Although at least some of the dirt-cheap supplies were kept out for protectionist purposes. Spot sugar prices in the "world free market" were 4.55 U.S. cents per pound on July 12, 1984; the corresponding (quota-protected) U.S. price was 21.95 cents per pound (Wall Street Journal, "Cash Prices," July 16, 1984, p. 28). During 1974 the "world free market"' sugar price reached a record high of 60 U.S. cents per pound.

14. Those data can be found in IMF, Direction of Trade Statistics, Yearbook 1984 (Washington, D.C., 1984).

15. For a decomposition of interest payments into those due to higher debt and those due to higher rates see Diaz-Alejandro, "1982-83 Brazilian Payments Crisis," p. 526. 
Assuming that export and import unit-value indexes give an accurate picture of price trends, we can use their average as the relevant international price level. ${ }^{16}$ While in the two earlier intervals these prices rose somewhat faster than U.S. wholesale prices, in the latest period they rose 9 percent per year slower. Thus the ex post real interest rate paid by Latin America during the early 1980s becomes about 9 percentage points higher than the already high real rate calculated using U.S. price indexes.

In sum, Latin American exports in 1981 were already feeling the international recession in a cyclical pattern that stretches back at least one hundred years in the economic history of these foreign-exchangedependent nations. Banks had become important suppliers of dollars; at first they continued lending, to some countries at an accelerated rate, but then they decided to stop, thereby curtailing even short-term trade credits. Apparently the stampede away from Latin America was led by banks with relatively small exposure to the region; U.S. money center banks are said to have persevered and even to have expanded their already substantial exposure. Countries without large reserves of international liquidity faced severe payments crises.

The 1982 behavior of lenders is difficult to reconcile with collective economic rationality. Even if new information appeared early in 1982 suggesting the wisdom of lower bank exposure in Latin America, the rational path toward that target was unlikely to coincide with the abrupt one chosen. The swing in capital flows after mid-1982 indicates that either lending was too high before, or that it was too low after, or both. Bank behavior during 1982 illustrates the financial markets' vulnerability to crises; such crises have, at their root, externalities that generate gaps between private and collective rationality. As expounded by theorists, lending during bad times takes on the character of a public good. ${ }^{17}$

Public goods must be supplied by collective action; this fact explains why since mid-1982 the Federal Reserve, the U.S. Treasury, the IMF, the Bank for International Settlements, and the large private banks took coordinated steps to create what I call an international credit orderly

16. The case of using a weighted sum of import and export dollar prices to deflate debt or interest payments, rather than other possible deflators, is presented in Bacha and DiazAlejandro, International Financial Intermediation, p. 12.

17. See Paul R. Krugman, "International Debt Strategies in an Uncertain World" (Massachusetts Institute of Technology, 1984); and Jeffrey D. Sachs, Theoretical Issues in International Borrowing, Studies in International Finance, 54 (Princeton University, International Finance Section, July 1984). 
marketing arrangement. But what may be seen from the lenders' viewpoint as actions correcting newly recognized market imperfections (so vehemently denied during ten years of discussions about the international economic order) appears from the borrowers' viewpoint rather like a credit cartel. A consortium in charge of distributing credit to remedy market failures should be expected to include borrowers as well as lenders. ${ }^{18}$ Otherwise, regulation motivated by a desire to correct externalities could spawn monopoly profits, a phenomenon amply documented in the history of regulation of many industries in OECD countries. In short, the 1982 collapse of a reasonably competitive, if flawed, international capital market (at least for Latin America) constitutes the major external shock to the region during the early 1980s.

\section{ADJUSTMENT POLICIES}

Perhaps the most important decisions adopted by Latin American countries since mid-1982 have been the continued servicing of the public external debt, even with delays and arrears, and the provision of extraordinary facilities for the servicing of the private external debt, which in some cases has been explicitly socialized. This behavior contrasts sharply with policies adopted during the early 1930s by most of the same countries. The question of whether to default will be reviewed below; the motivation for a non-laissez faire policy toward private external debt will be briefly discussed now.

Even a government strong enough to ignore political pressure from private lobbies may hesitate to allow the bankruptcy of major financial and nonfinancial firms. The externalities of bankruptcies are clearest for private financial intermediaries; but even the bankruptcies of nonfinancial firms may be viewed as aggravating recessions and destroying public goods laboriously built up over many years of nurturing "infant" corporations. This is particularly true in countries with relatively scarce entrepreneurial endowments and in which highly imperfect domestic capital markets and clumsy bankruptcy laws could push sound organizations over the brink. Most of what can be said in favor of the Chrysler

18. As put by Charles P. Kindleberger, "the role of the lender of last resort is to provide the public good of stability, rather than to serve a class, caste, national, or private purpose." Kindleberger, Manias, Panics, and Crashes: A History of Financial Crises (Basic Books, 1978), p. 223. 
rescue would apply a fortiori for the Grupo Alfa and other such Latin American rescues. Fears that foreigners may take over troubled domestic firms add to the case for bailouts. Note that in many countries, private local banks guaranteed the loans of local firms that borrowed abroad; the bankruptcy of those firms threatened local banks and raised specters of either a major financial panic or wholesale acquisition of the private sector by foreigners.

Why such publicly sponsored rescues of troubled corporations have come via subsidies to the servicing of their external debts requires further explanation. One reason is that the debt-servicing burden following massive devaluations is so large. Another is that private international banks have pressed Latin American countries to help corporations indebted to those banks. The pressure has not been subtle. "San Francisco-based Wells Fargo Bank, for instance, has threatened several times to declare [Venezuelan] public-sector loans in default if payments on the private debts weren't brought up to date." 19 The Colombian government was said to be under pressure during 1984 to take up the debt of some Colombia-owned private banks incorporated in Panama. Now that banks can coordinate their actions without fear of antitrust objections, a threat to squeeze short-term trade credits has proven most effective in bringing reluctant countries to heel on the issue of private debts during debt-rescheduling exercises.

Had one proposed in 1980-81 that no Latin American private firms be allowed to borrow abroad without government permission, one would have been accused of gross interventionism or worse. Such complete control over foreign borrowing has now been imposed on Latin American governments, even on those most committed to laissez faire, by the international credit consortium.

The troubles of indebted Latin American enterprises both public and private have been undoubtedly aggravated by the abrupt and massive devaluations of the early 1980s. As shown in table 1, the real devaluations have been larger when measured against the dollar than against currency

19. This is a direct quote from Dorreen Hemlock, "Bureaucratic Logjam Delays Venezuelan Debt," Wall Street Journal, July 27, 1984, p. 22. The article also states that "at first, the banks even refused to negotiate the government debt until Caracas approved subsidies for $\$ 2.5$ billion of private debt. Bankers were willing to start talks this week, because, they say, they see signs the private-debt impasse is easing." The Venezuelan government is said to have had the nerve to limit subsidies to net debt-the difference between a company's foreign debt and its holdings overseas-and there the troubles began. 
baskets; nevertheless, the devaluations in Argentina (since 1980), Brazil (since 1982), Chile (since 1981), and Mexico (since 1981) have been remarkable. In most countries the devaluation would loom even larger if it were deflated by money wages; that is, real wages in terms of tradable goods and services appear to have declined steeply. (During 1983 Venezuela adopted multiple exchange rates not reflected in table 1.) One may note that few alert businessmen or foreign bankers should have been surprised by these real devaluations, even if their timing and magnitude were uncertain. Spreads over LIBOR (London interbank offered rate) were supposed to cover, among other things, risks arising from abrupt change in the business environment.

As they were during the early 1930s, the devaluations were more or less forced by circumstances and came only after socially expensive dollars from central-bank reserves were cheaply sold in vain attempts to maintain parities. Once the real devaluations came, a battery of other import-repressing mechanisms were reinforced or reintroduced. Even in Mexico and Venezuela, used to free currency convertibility in the past, "temporary" exchange controls were enacted and have been retained: the barn door was locked after most of the horses had fled. Brazil and Colombia had exchange controls in place at the outset of the crisis and have thus managed real devaluations and other policy changes in a more orderly fashion.

The harshness of import and exchange controls during 1982-84 has varied considerably among the six countries: Brazilian and Colombian import controls are much tighter than those of Chile; Mexican exchange controls are administered by officials who abhor them, in contrast with officials in Argentina and Colombia; and the Chilean tariff, although raised relative to pre-1982 levels, remains as of August 1984 one of the lowest in Latin America, while the Brazilian one is impenetrable.

Monetary and fiscal policies of the six have moved toward a more restrictive stance. Monetary expansion fell substantially behind inertial and corrective inflation during 1983 in Brazil and Mexico; table 7 also shows that domestic credit (to the private and public sectors) has expanded less than inflation in Chile and Mexico during 1983. The other three countries, which are without standby agreements with the IMF as of August 1984, showed less contraction in real money and credit during 1983. Of these three countries, inflation accelerated alarmingly only in Argentina; during 1983 Colombia and Venezuela registered inflation 
Table 7. Credit, Money, and Prices in Second and Fourth Quarters, 1981-83

Percent change from same period in previous year

\begin{tabular}{|c|c|c|c|c|c|c|}
\hline \multirow{2}{*}{$\begin{array}{l}\text { Country } \\
\text { and } \\
\text { measure }\end{array}$} & \multicolumn{2}{|c|}{1981} & \multicolumn{2}{|c|}{1982} & \multicolumn{2}{|c|}{1983} \\
\hline & $\begin{array}{l}\text { Second } \\
\text { quarter }\end{array}$ & $\begin{array}{l}\text { Fourth } \\
\text { quarter }\end{array}$ & $\begin{array}{l}\text { Second } \\
\text { quarter }\end{array}$ & $\begin{array}{l}\text { Fourth } \\
\text { quarter }\end{array}$ & $\begin{array}{l}\text { Second } \\
\text { quarter }\end{array}$ & $\begin{array}{l}\text { Fourth } \\
\text { quarter }\end{array}$ \\
\hline \multicolumn{7}{|l|}{ Argentina } \\
\hline Credit & 150 & 209 & 177 & 224 & 313 & 401 \\
\hline Money & 42 & 70 & 145 & 248 & 327 & 362 \\
\hline Prices & 89 & 123 & 130 & 203 & 314 & 404 \\
\hline \multicolumn{7}{|l|}{ Brazil } \\
\hline Credit & 55 & 68 & 103 & 129 & 150 & 178 \\
\hline Money & 57 & 75 & 77 & 71 & 87 & 90 \\
\hline Prices & 106 & 106 & 99 & 98 & 120 & 175 \\
\hline \multicolumn{7}{|l|}{ Chile } \\
\hline Credit & 41 & 30 & 58 & 75 & 26 & 11 \\
\hline Money & 29 & -6 & -11 & 9 & 34 & 27 \\
\hline Prices & 23 & 11 & 5 & 19 & 31 & 24 \\
\hline \multicolumn{7}{|l|}{ Colombia } \\
\hline Credit & 46 & 39 & 42 & 41 & 43 & 39 \\
\hline Money & 24 & 21 & 24 & 25 & 16 & 23 \\
\hline Prices & 27 & 27 & 25 & 25 & 22 & 17 \\
\hline \multicolumn{7}{|l|}{ Mexico } \\
\hline Credit & 46 & 50 & 75 & 113 & 79 & 49 \\
\hline Money & 35 & 33 & 31 & 65 & 54 & 40 \\
\hline Prices & 28 & 29 & 44 & 88 & 115 & 87 \\
\hline \multicolumn{7}{|l|}{ Venezuela } \\
\hline Credit & 1 & 21 & 56 & 22 & 12 & 6 \\
\hline Money & 14 & 10 & 4 & 6 & 11 & 21 \\
\hline Prices & 18 & 12 & 10 & 8 & 6 & 7 \\
\hline
\end{tabular}

Source: IMF, International Financial Statistics, various issues; credit, line 32; money, line 34; prices, line 64. a. Credit refers to "domestic credit." Credit and money are at end of period. Domestic credit plus net foreign assets equals money plus quasi money plus net other liabilities of the banking system. Prices refer to consumer prices, period averages.

lower even than Chile's. All governments have pledged austerity in public expenditures, particularly those involving foreign exchange. By mid-1984 only Argentina (and perhaps Colombia) lacked an overall stabilization program that could be regarded as contractionary. In all countries, public investments in particular have been sharply reduced. ${ }^{20}$

20. Comparable, meaningful, and up-to-date information on fiscal performance remains elusive, to a large extent owing to the inability or unwillingness of national and multilateral bodies to estimate deficits using inflation accounting and to separate cyclical from structural deficits. 
Real devaluations have had important fiscal consequences, increasing the real burden of debt servicing and reducing customs revenues. On the other hand, where government accounts for a good share of the export sector, as it does in Mexico and Venezuela, real devaluations have generated fiscal windfalls.

\section{OVERALL ECONOMIC PERFORMANCE}

As in many previous stabilization crises in Latin America, the balance of payments, particularly the trade balance, has been turned around remarkably fast, especially in countries adopting stiff devaluations and monetary restrictions; on the other hand, advances in the battle against inflation have been disappointing even among the "well behaved." As a rule, real absorption and GDP have done worst in countries with the sharpest improvements in trade balances; investments and imports have declined precipitously in countries whose balance of payments performances generate euphoria in the international financial press. Unemployment and poverty indicators are scarce and not very reliable, but they appear to be at higher levels than during 1980-81.

Except in Colombia and Venezuela, impressive changes in trade accounts were made between 1980-81 and 1982-83 (table 8). By 1983 Mexico and Venezuela had trade surpluses exceeding their net factor payments (interest and profits) abroad; in Argentina, Brazil, and Chile the trade surpluses were more than half of factor payments abroad during 1983. Again excepting Colombia, current account deficits in 1983 were below those of the three previous years; Mexico and Venezuela even had current account surpluses, which are expected to continue during 1984. Behind the impressive current account performance lie sharp reductions in real expenditures, particularly investment, and expenditure switching induced by new controls and drastic changes in relative prices. Imports have responded more rapidly than exports to policies inducing expenditure reduction, expenditure switching, and expenditure repression.

The view of the capital account of the balance of payments during 1982-83 is murkier, partly owing to less complete or older data. Through the murkiness, however, one can see some alarming developments. Consider first the changes in public, private, and short-term debt between the end of 1981 and the end of 1983, and contrast those changes with 
Table 8. Trade and Other Balances, 1980-83

Billions of U.S. dollars

\begin{tabular}{|c|c|c|c|c|}
\hline Country and measure & 1980 & 1981 & 1982 & 1983 \\
\hline $\begin{array}{l}\text { Argentina } \\
\text { Trade balance, f.o.b. } \\
\text { Net factor payments } \\
\text { Other services, net } \\
\text { Current account }\end{array}$ & $\begin{array}{l}-1.37 \\
-1.61 \\
-1.79 \\
-4.77\end{array}$ & $\begin{array}{r}0.71 \\
-3.93 \\
-1.49 \\
-4.71\end{array}$ & $\begin{array}{r}2.72 \\
-5.11 \\
-0.09 \\
-2.48\end{array}$ & $\begin{array}{r}3.61 \\
-5.86 \\
-0.32 \\
-2.57\end{array}$ \\
\hline $\begin{array}{l}\text { Brazil } \\
\text { Trade balance, f.o.b. } \\
\text { Net factor payments } \\
\text { Other services, net } \\
\text { Current account }\end{array}$ & $\begin{array}{r}-2.82 \\
-7.04 \\
-2.98 \\
-12.85\end{array}$ & $\begin{array}{r}1.18 \\
-10.27 \\
-2.67 \\
-11.76\end{array}$ & $\begin{array}{r}0.78 \\
-13.51 \\
-3.58 \\
-16.31\end{array}$ & $\begin{array}{r}6.47 \\
-11.70 \\
-2.33 \\
-7.56\end{array}$ \\
\hline $\begin{array}{l}\text { Chile } \\
\text { Trade balance, f.o.b. } \\
\text { Net factor payments } \\
\text { Other services, net } \\
\text { Current account }\end{array}$ & $\begin{array}{l}-0.76 \\
-1.03 \\
-0.23 \\
-2.02\end{array}$ & $\begin{array}{l}-2.68 \\
-1.60 \\
-0.54 \\
-4.82\end{array}$ & $\begin{array}{r}0.06 \\
-2.03 \\
-0.41 \\
-2.38\end{array}$ & $\begin{array}{r}1.01 \\
-1.81 \\
-0.42 \\
-1.22\end{array}$ \\
\hline $\begin{array}{l}\text { Colombia } \\
\text { Trade balance, f.o.b. } \\
\text { Net factor payments } \\
\text { Other services, net } \\
\text { Current account }\end{array}$ & $\begin{array}{r}-0.24 \\
-0.18 \\
0.26 \\
-0.16\end{array}$ & $\begin{array}{r}-1.54 \\
-0.40 \\
0.05 \\
-1.89\end{array}$ & $\begin{array}{r}-2.42 \\
-0.88 \\
0.10 \\
-3.20\end{array}$ & $\begin{array}{r}-1.64 \\
-0.68 \\
0.17 \\
-2.15\end{array}$ \\
\hline $\begin{array}{l}\text { Mexico } \\
\text { Trade balance, f.o.b. } \\
\text { Net factor payments } \\
\text { Other services, net } \\
\text { Current account }\end{array}$ & $\begin{array}{r}-2.83 \\
-6.21 \\
0.73 \\
-8.31\end{array}$ & $\begin{array}{r}-4.10 \\
-9.53 \\
-0.44 \\
-14.07\end{array}$ & $\begin{array}{r}6.79 \\
-10.86 \\
-1.25 \\
-5.32\end{array}$ & $\begin{array}{r}13.68 \\
-8.98 \\
0.62 \\
5.32\end{array}$ \\
\hline $\begin{array}{l}\text { Venezuela } \\
\text { Trade balance, f.o.b. } \\
\text { Net factor payments } \\
\text { Other services, net } \\
\text { Current account }\end{array}$ & $\begin{array}{r}8.17 \\
0.33 \\
-3.75 \\
4.75\end{array}$ & $\begin{array}{r}7.84 \\
0.57 \\
-4.39 \\
4.03\end{array}$ & $\begin{array}{r}2.75 \\
-1.53 \\
-5.44 \\
-4.22\end{array}$ & $\begin{array}{r}7.16 \\
-2.02 \\
-1.61 \\
3.53\end{array}$ \\
\hline
\end{tabular}

Source: Same as table 3 .

a. Trade balance is defined as merchandise exports minus imports, both valued f.o.b. Negative values refer to debit items in the balance of payments.

\section{earlier trends. ${ }^{21}$ Increases in private and short-term debt during 1981-83 represent a smaller share in the change of total external debt than during}

21. This paragraph relies on data presented in Inter-American Development Bank, External Debt and Economic Development in Latin America: Background and Prospects (Washington, D.C., January 1984). "Public" includes disbursed public and private debt with official guarantee and original maturity term greater than one year. "Private" includes disbursed private debt without official guarantee, maturity greater than one year. Shortterm debt includes both private and public debt. Data for 1983 are preliminary estimates. 


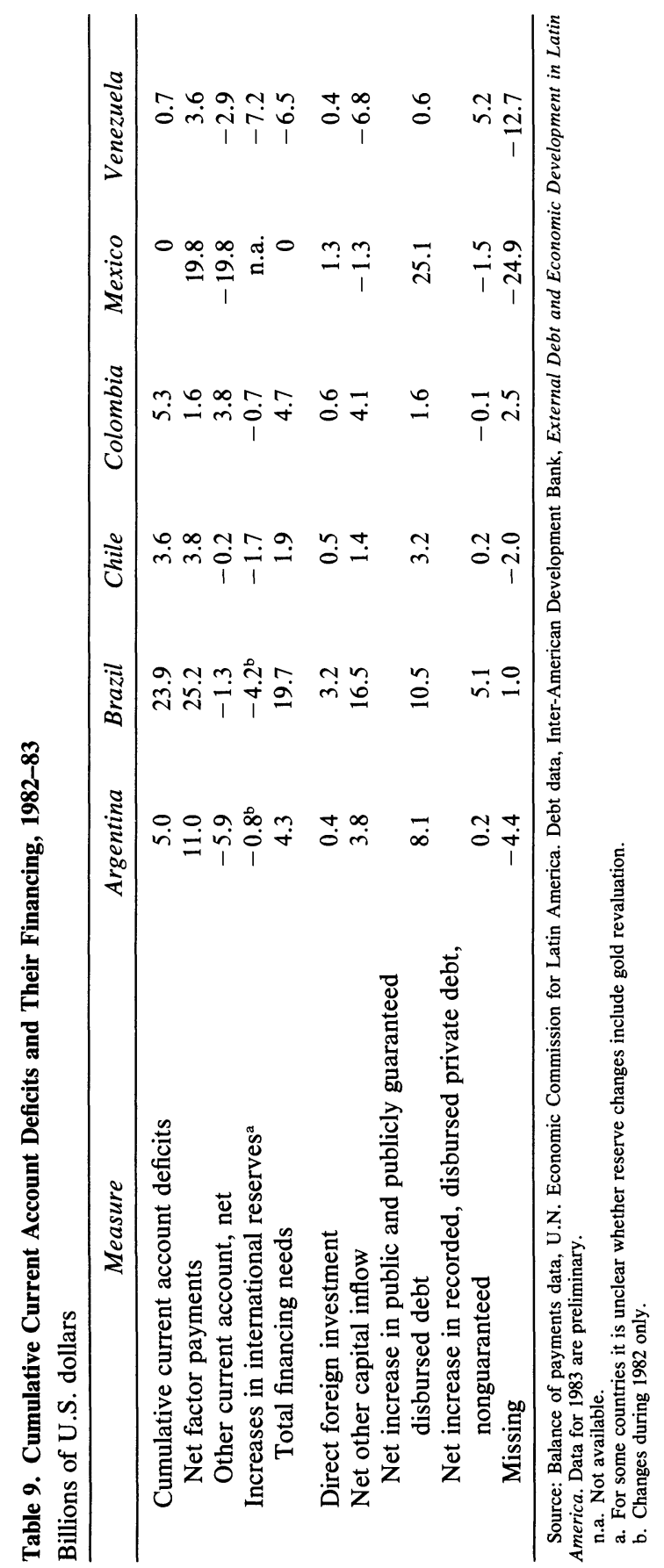


1975-81 (except possibly in Brazil, where data are especially shaky). The change is drastic for Argentina, Chile, and Mexico, countries that relied heavily on private and short-term debt before 1982 . The Mexican data for 1982-83 dramatize what appears to have occurred in several other countries as well: a good share of the increase in registered public debt during those two years went either to "clean up" unregistered public short-term debt or to cover reductions in registered private sector external liabilities, whether long or short term.

Combining the data on long-term debt (short-term debt cannot be divided into private and public) with current account results for 198283 , one obtains astonishing estimates for previously unrecorded shortterm public debt plus net unregistered private capital outflows for Mexico and Venezuela and, to a lesser extent, for Argentina and Chile. These are presented in table 9, where the large sums categorized as "missing" can be contrasted with the estimates for earlier years given in table 3. Only Brazil and Colombia, with their traditional and creaky exchange controls, appear to have escaped unregistered short-term public indebtedness or massive capital flight during 1982-83. ${ }^{22}$ Table 9 also shows that during 1982-83 only Colombia experienced a net resource inflow, defined as a deficit in the current account excluding factor payments.

The worst aspect of Latin American macroeconomic performance during 1982 and 1983 is not to be found so much in the contraction of absorption (total expenditures) and output, bad as those were, particularly in per capita terms; the worst was the violent reduction in investment, which impaired not only present but future growth, even granting the existence of substantial excess capacity. The oil countries have not escaped savage cutbacks in capital formation; only Colombia escaped this trend during 1982-83 (table 10). Among the components of investment, machinery and equipment was especially weak in most countries

22. The U.N. Economic Commission for Latin America estimates "errors and omissions" for the all-Latin America balance of payments at $\$ 17$ billion for 1982 plus 1983; the sum for 1980 plus 1981 was $\$ 16$ billion. See U.N. Economic Commission for Latin America, Adjustment Policies and Renegotiation of the External Debt, E/CEPAL/SES.20/G.17 (New York, February 22, 1984), table 2, p. 11. The Bank for International Settlements estimates that some $\$ 50$ billion flowed out of Latin America between 1978 and 1982 (Economist, June 23, 1984, p. 73). The conceptual bases for these estimates differ, however, from those in table 9 . Nevertheless, the case can be made that the methodology used in table 9 would reveal even greater capital flight if 1981 had been combined with $1982-83$ rather than with earlier years. 


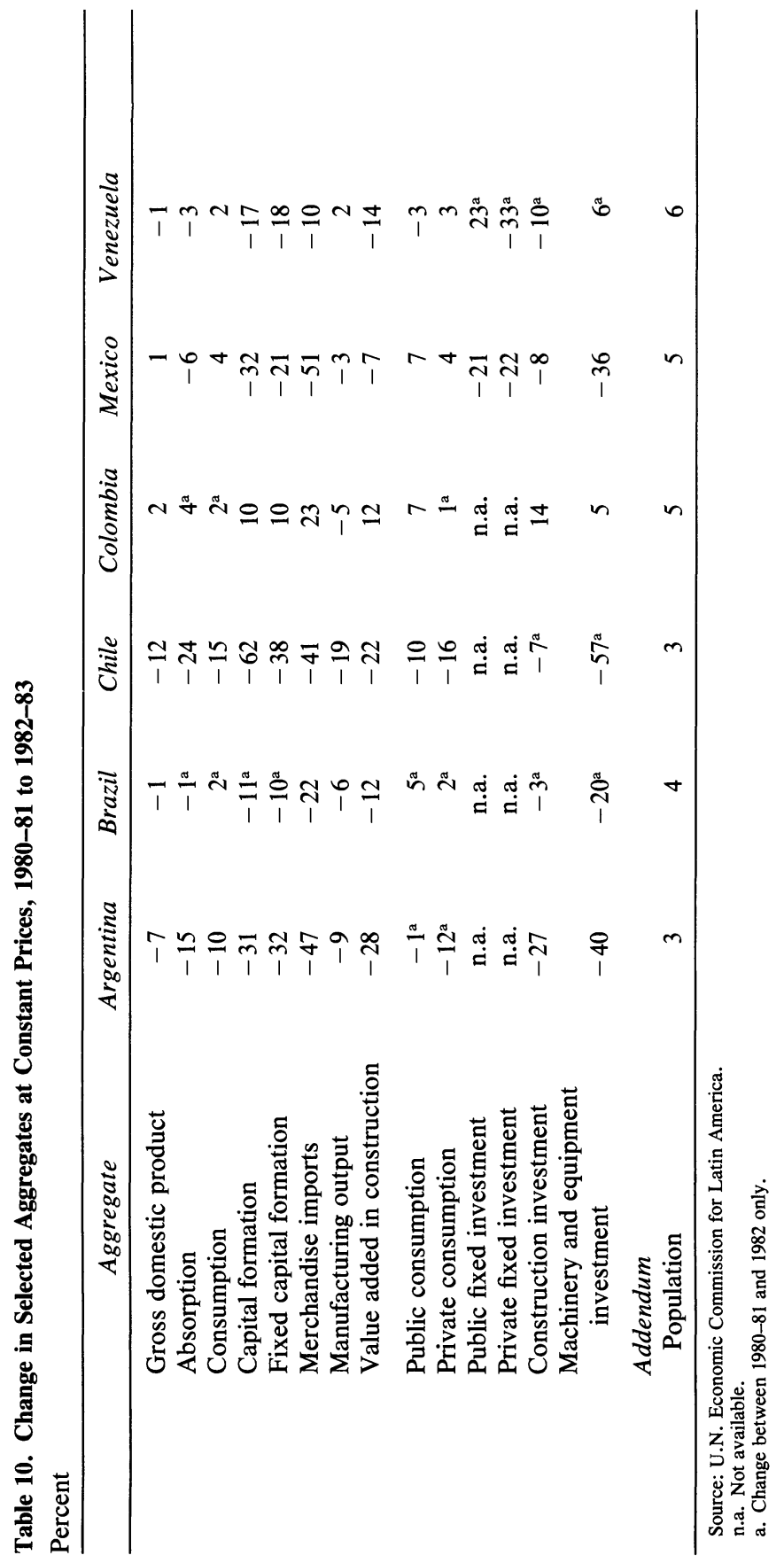


and only Colombia sensibly expanded labor-intensive construction activity that did not use imports. Table 10 also shows remarkable contractions in import volume between 1980-81 and 1982-83 for Argentina, Chile, and Mexico and, to a lesser extent, for Brazil and Venezuela. Colombia, drawing on reserves accumulated during the coffee bonanza, managed to expand import volume during 1982-83. Except in Colombia, absorption declined no less than total output; Chile's declines in absorption and consumption are the steepest. Argentine and Brazilian macroeconomic indicators would look worse if 1982-83 were compared with only 1980.

It could be that during 1982-83, aggregate supply in Latin American countries declined more than the reductions shown in table 10 for aggregate demand; the region, after all, experienced low terms of trade and less favorable external credit. Capacity built up before 1982 may have become obsolete owing to abrupt changes in relative prices. Persistent inflation during 1982-83 (shown in table 7) could thus be blamed on excess demand presumably generated by the public sector. But this story seems unpersuasive, particularly in explaining the high levels of Brazilian and Mexican inflations during 1983 and the first half of 1984. Those who call for further reductions in aggregate demand in Brazil and Mexico are likely to be more interested in beefing up the trade surpluses of those countries than in eliminating inflation. Inflation is likely to persist, driven in the short run by necessary changes in relative prices (such as the real devaluation) as well as by other inertial factors. The coexistence of a "favorable" current account and very high inflation in both Brazil and Mexico during 1983 and early 1984 erodes the credibility of those who argue that elimination of inflation is indispensable for improving the balance of payments. The performance of these two countries during 1983 also casts doubt on the universal applicability of the formula so popular among some staff members of the IMF that "the current account deficit equals the budget deficit."

Declines in aggregate absorption and output appear to have been accompanied by changes in income and wealth distribution, although it is not possible to quantify these shifts. Producers of exportables and import-competing goods and holders of net dollar assets have reaped windfall gains from the real devaluations. Producers of nontraded goods, most wage earners, and those with net dollar liabilities (including the public sector) seem to have borne most of the burden of adjustment. 
Scattered evidence suggests increases in unemployment and in the number of persons below the poverty line. In Brazil there have been reports of a decline in per capita food consumption to levels below that of 1980 .

As may be seen in the following year-to-year percentage changes, industrial real wages fell sharply during 1983 in Brazil, Chile, and Mexico; the lame-duck Argentine military government, after years of suppressing real wages, engineered a destabilizing increase during $1983 .{ }^{23}$

$\begin{array}{lrrrc} & & & & \text { Cumulative, } \\ & 1981 & 1982 & 1983 & 1980-83 \\ \text { Argentina } & -11 & -10 & 29 & 3 \\ \text { Brazil } & 6 & 7 & -12 & 1 \\ \text { Chile } & 12 & -3 & -11 & -4 \\ \text { Colombia } & 0 & 4 & 3 & 7 \\ \text { Mexico } & 3 & -1 & -25 & -24 \\ \text { Venezuela } & -3 & 3 & -3 & -3\end{array}$

The gap between gross national product and GDP reached levels not witnessed since the 1920 s in most countries. Net factor payments abroad (interest plus profits) as a percent of GDP during 1982-83 may be estimated at 6 for Argentina, 5 for Brazil, more than 10 for Chile, and 4 for Mexico. These percentages, of course, would be higher if one compared net factor payments abroad with domestic savings.

The 1982-83 crisis, which in Argentina and Brazil was clearly visible already in 1981, has had negative repercussions beyond those registered in national accounts and social indicators. Domestic financial systems have been deeply shaken. Many financial and nonfinancial firms in the private sector are bankrupt, either de facto or de jure. In many cases, government "interventions" in those firms have left their legal status in limbo, further reducing investment incentives. The precarious status of domestic financial intermediaries has reduced incentives to save and has induced further capital outflows by domestic residents. Sundry financial scandals involving previously respected personalities, together with bankruptcies and capital flight, have eroded the legitimacy of the previous "mixed" Latin American development model. Almost a whole generation of national entrepreneurs and financiers has been discredited;

23. Data from International Labor Office, PREALC Newsletter, no. 4 (August 1984), p. 4. These data cover mainly workers in large industrial establishments. PREALC (the International Labor Office branch in Latin America) conjectures that the real wages for other workers have suffered far greater deterioration than those shown here. 
alternatives to them, besides foreign ones or those tainted by illegal activities, are not easily found.

To summarize, the performance of the real Latin American economy since 1981 has been dominated by the balance of payments, which in turn has been dominated by the need to service debt and obtain some fresh external loans. A few hairs wagged the tail that wagged the dog. The contrast with the early 1930s is interesting: the external shocks were then even more severe than those of the early 1980s, but per capita GDP, absorption, and especially manufacturing output performed then no worse than during the early 1980s, at least in Argentina, Brazil, and even Colombia. ${ }^{24}$ So far, the 1980 s crisis has not had the positive side benefits of the 1930s crisis, such as greater self-reliance in the financing of capital formation, new public and private institutions, and a new crop of local entrepreneurs.

\section{Three Crucial Functions: An Econometric Interlude}

Three important variables, discussed above, deserve closer scrutiny: import volume, exports, and the real exchange rate. What follows should help to place their recent and somewhat dramatic behavior within a longer-term context and to explore whether that behavior can be "explained" by other, more-or-less exogenous variables. No complete model will be presented; but the reduced-form, single-equation regressions of this section may clarify whether the recent cycle is much different from previous ones and what recent changes imply for the future.

\section{IMPORT FUNCTIONS}

All economies under study operated under import (and exchange) controls during part or all of 1960-83. Under these circumstances, estimating import functions is a difficult affair. Table 11 presents a roughand-ready attempt to probe behind the steep fall in import volume during recent years: the major hypothesis is that different components of

24. See Carlos F. Diaz-Alejandro, "Stories of the 1930s for the 1980s," in Pedro Aspe Armella and others, eds., Financial Policies and the World Capital Market: The Problem of Latin American Countries (University of Chicago Press, 1983), pp.7-9. The performance of Brazilian output was clearly better during 1929-33 than during the early 1980 s. 
Table 11. Regressions for Import Propensities from Investment and Other Absorption, 1960 through 1982 or $1983^{\mathrm{a}}$

\begin{tabular}{|c|c|c|c|c|c|c|}
\hline $\begin{array}{c}\text { Independent } \\
\text { variable }\end{array}$ & Argentina & Brazil & Chile & Colombia & Mexico & Venezuela \\
\hline Intercept & $\begin{array}{c}-1030 \\
(-1.30)\end{array}$ & $\begin{array}{c}299 \\
(0.92)\end{array}$ & $\begin{array}{c}-428 \\
(-3.13)\end{array}$ & $\begin{array}{c}150 \\
(0.87)\end{array}$ & $\begin{array}{c}-1323 \\
(-5.57)\end{array}$ & $\begin{array}{c}-1237 \\
(-7.30)\end{array}$ \\
\hline $\begin{array}{l}\text { Investment } \\
\text { in machinery } \\
\text { and equipment }\end{array}$ & $\begin{array}{c}0.34 \\
(1.68)\end{array}$ & $\begin{array}{c}0.40 \\
(5.70)\end{array}$ & $\begin{array}{c}0.68 \\
(4.05)\end{array}$ & $\begin{array}{c}1.50 \\
(9.37)\end{array}$ & $\begin{array}{c}0.67 \\
(12.21)\end{array}$ & $\begin{array}{c}0.52 \\
(5.57)\end{array}$ \\
\hline Other absorption & $\begin{array}{c}0.09 \\
(1.66)\end{array}$ & $\begin{array}{c}0.03 \\
(1.97)\end{array}$ & $\begin{array}{c}0.11 \\
(4.24)\end{array}$ & $\begin{array}{c}-0.09 \\
(-2.15)\end{array}$ & $\begin{array}{c}0.10 \\
(5.64)\end{array}$ & $\begin{array}{c}0.38 \\
(8.81)\end{array}$ \\
\hline Trend & $\begin{array}{c}-54 \\
(-1.49)\end{array}$ & $\begin{array}{c}-120 \\
(-1.85)\end{array}$ & $\begin{array}{c}7 \\
(1.54)\end{array}$ & $\begin{array}{c}23 \\
(1.09)\end{array}$ & $\begin{array}{c}-340 \\
(-8.35)\end{array}$ & $\begin{array}{c}-174 \\
(-6.80)\end{array}$ \\
\hline Summary statistic & & & & & & \\
\hline $\begin{array}{l}\bar{R}^{2} \\
\text { Autoregressive } \\
\quad \text { parameter } \\
\begin{array}{c}\text { Degrees } \\
\text { of freedom }\end{array}\end{array}$ & -0.58 & -0.45 & -0.45 & 0.08 & 0.22 & -0.11 \\
\hline
\end{tabular}

absorption have very different marginal import propensities, and in particular, investment in machinery and equipment is presumed to have the highest import component of all major absorption categories. Because disaggregated import volume data are not available for the whole period, the hypothesis has been tested indirectly by making all import volume depend on the different absorption components.

The fits shown in table 11 are remarkably good; the regressions indicate that investment in machinery and equipment induces far more imports than other expenditures, even in countries with the most advanced domestic capital goods industries (Brazil and Mexico). Even if one discounts these results somewhat (especially those for Colombia), they help to explain the brutal 1982-83 decline in imports. Squeezing investment, especially in machinery and equipment, is an "effective" way to reduce imports in semi-industrialized economies and may obviate the need to further squeeze other absorption for balance of payments reasons. A recovery of growth, particularly one that expands investment beyond housing and structures, would require sharpincreases in imports, ceteris paribus. 
Table 12. Regressions for Exchange Rate Elasticity of Imports, 1960 through 1982 or $1983^{a}$

\begin{tabular}{|c|c|c|c|c|c|c|}
\hline $\begin{array}{c}\text { Independent } \\
\text { variable }\end{array}$ & Argentina & Brazil & Chile & Colombia & Mexico & Venezuela \\
\hline Intercept & $\begin{array}{c}-0.04 \\
(-1.19)\end{array}$ & $\begin{array}{l}-0.11 \\
(-2.34)\end{array}$ & $\begin{array}{c}-0.01 \\
(-0.67)\end{array}$ & $\begin{array}{c}-0.08 \\
(-1.38)\end{array}$ & $\begin{array}{c}-0.16 \\
(-3.33)\end{array}$ & $\begin{array}{c}-0.07 \\
(-3.21)\end{array}$ \\
\hline $\begin{array}{l}\text { Change in ln } \\
\text { of investment } \\
\text { in machinery } \\
\text { and equipment }\end{array}$ & $\begin{array}{c}0.54 \\
(4.14)\end{array}$ & $\begin{array}{c}0.14 \\
(1.37)\end{array}$ & $\begin{array}{c}0.31 \\
(3.08)\end{array}$ & $\begin{array}{c}1.20 \\
(4.37)\end{array}$ & $\begin{array}{c}0.31 \\
(1.63)\end{array}$ & $\begin{array}{c}0.37 \\
(4.01)\end{array}$ \\
\hline $\begin{array}{l}\text { Change in ln } \\
\text { of other } \\
\text { absorption }\end{array}$ & $\begin{array}{c}1.32 \\
(3.04)\end{array}$ & $\begin{array}{c}2.38 \\
(3.77)\end{array}$ & $\begin{array}{c}1.27 \\
(4.88)\end{array}$ & $\begin{array}{c}1.63 \\
(1.42)\end{array}$ & $\begin{array}{c}3.16 \\
(3.47)\end{array}$ & $\begin{array}{c}1.94 \\
(5.14)\end{array}$ \\
\hline $\begin{array}{l}\text { Change in ln } \\
\text { of real } \\
\text { exchange rate }\end{array}$ & $\begin{array}{c}-0.07 \\
(-1.05)\end{array}$ & $\begin{array}{c}-0.78 \\
(-2.50)\end{array}$ & $\begin{array}{l}-0.26 \\
(-1.88)\end{array}$ & $\begin{array}{c}0.03 \\
(0.08)\end{array}$ & $\begin{array}{c}-0.43 \\
(-2.39)\end{array}$ & $\begin{array}{c}-0.61 \\
(-3.29)\end{array}$ \\
\hline $\begin{array}{l}\text { Change in ln } \\
\text { of real } \\
\text { exchange rate, } \\
\text { lagged }\end{array}$ & $\begin{array}{c}-0.38 \\
(-5.51)\end{array}$ & $\begin{array}{c}-0.32 \\
(-1.01)\end{array}$ & $\cdots$ & $\cdots$ & $\cdots$ & $\cdots$ \\
\hline Summary statistic & & & & & & \\
\hline $\begin{array}{l}R^{2} \\
\text { Autoregressive } \\
\quad \text { parameter } \\
\text { Degrees } \\
\text { of freedom }\end{array}$ & $\begin{array}{c}0.90 \\
-0.41 \\
17\end{array}$ & $\begin{array}{c}-0.16 \\
16\end{array}$ & -0.00 & 0.23 & $\begin{array}{c}-0.38 \\
18\end{array}$ & -0.01 \\
\hline
\end{tabular}

Source: See tables 1 and 11 .

a. Dependent variable is the change in the natural log of import volume. Annual data. Real dollar exchange rate, as in table 1. Numbers in parentheses are $t$-statistics.

The regressions of table 11 , which were specified so as to sort out separate import propensities, were not suited for estimating the elasticity of imports with respect to the real exchange rate. Estimates of this elasticity are made with the logarithmic regressions presented in table 12. Those coefficients may be picking up not just expenditure-switching effects of changes in relative prices but also the import-repressing consequences of tighter controls adopted together with real depreciations. (It is assumed that the contemporaneous real exchange rate may be taken as exogenous and independent of import volume.) In spite of these caveats, the estimates are reasonably good and give some hope that the import substitution induced by $1982-83$ policies will be a substantial component of economic recovery. Both the trend variable in 
table 11 and the intercept in table 12 indicate significant secular import substitution for Brazil, Mexico, and Venezuela.

Other import functions were estimated by relying on aggregates such as GDP, all absorption, industrial output, consumption, and all investment. The regressions of tables 11 and 12 not only yield the best fits but also make the most sense. Import elasticities with respect to simple aggregates such as GDP or all absorption are extravagantly high. For detailed projections, an even more disaggregated approach would be desirable. For example, Brazilian import behavior will be significantly influenced by domestic oil and other fuel production and by advances in other lumpy import-substituting activities such as those in nonferrous metals.

\section{EXPORT FUNCTIONS}

Domestic policies as well as sundry internal and external shocks influence Latin American export earnings. A complete examination of export performance should disaggregate by goods and markets the external demand and domestic supply of major export items. The smallcountry assumption is convenient for purposes of modeling and estimation, but it is probably not quite accurate, especially for the conditions of the early 1980s. A complete specification of the export sector would involve quota-constrained demand functions as well as supply schedules sensitive to degrees of domestic capacity utilization. But such a study is beyond the scope of this paper, which will limit itself to estimating a reduced form of the export functions.

The celebrated Cline study started a fruitful controversy on the precise link between the growth of industrialized countries, on one side, and the expansion of exports from developing countries, on the other. ${ }^{25}$ Table 13 represents my contribution to that debate. The dependent variable in table 13 is the percentage change in the purchasing power of merchandise exports. As already noted, the purchasing power of exports is equal to

25. William R. Cline, International Debt and the Stability of the World Economy, Policy Analyses in International Economics, 4 (Washington, D.C.: Institute for International Economics, September 1983). See also Albert Fishlow, "Coping with the Creeping Crisis of Debt," Working Paper 181 (University of California at Berkeley, Department of Economics, February 1984); and Rudiger Dornbusch and Stanley Fischer, "The World Debt Problem' (Massachusetts Institute of Technology, Department of Economics, May 1984). 
Table 13. Regressions for Purchasing Power of Merchandise Exports, 1960 through $1983^{\mathrm{a}}$

\begin{tabular}{lcccccc}
\hline $\begin{array}{c}\text { Independent } \\
\text { variable }\end{array}$ & Argentina & Brazil & Chile & Colombia & Mexico & Venezuela \\
\hline Intercept & -7.16 & -3.23 & -11.40 & -1.38 & 15.75 & 17.95 \\
& $(-1.17)$ & $(-0.61)$ & $(-1.49)$ & $(-0.21)$ & $(2.22)$ & $(1.30)$ \\
$\begin{array}{l}\text { OECD GNP } \\
\quad \text { growth }\end{array}$ & 3.40 & 2.65 & 3.70 & 1.59 & -1.35 & -3.18 \\
$\begin{array}{l}\text { OECD GNP } \\
\quad \text { acceleration, }\end{array}$ & $4.63)$ & $(2.10)$ & $(2.06)$ & $(1.00)$ & $(-0.80)$ & $(-0.92)$ \\
$\quad$ lagged & $(3.14)$ & $(1.08)$ & $(2.36)$ & $(0.48)$ & $(1.53)$ & $(1.43)$ \\
$\begin{array}{l}\text { Real exchange rate } \\
\text { change, lagged }\end{array}$ & 0.11 & 0.57 & 0.70 & 0.10 & 0.10 & -0.13 \\
$\begin{array}{l}\text { Summary statistic } \\
\bar{R}^{2}\end{array}$ & $(1.40)$ & $(1.95)$ & $(2.17)$ & $(0.24)$ & $(0.41)$ & $(-0.15)$ \\
$\begin{array}{l}\text { Durbin-Watson } \\
\text { Degrees }\end{array}$ & 0.57 & 0.38 & 0.47 & 0.09 & 0.12 & 0.12 \\
$\quad$ of freedom & 1.94 & 2.12 & 2.21 & 2.24 & 1.12 & 1.82 \\
\hline
\end{tabular}

Source: Basic export data, U.N. Economic Commission for Latin America. Industrial countries' growth rates, IMF, International Financial Statistics, Yearbook 1983.

a. Dependent variable is the percent change in the purchasing power of merchandise exports (see text). Annual data. Real dollar exchange rates, as in table 12. Numbers in parentheses are $t$-statistics.

the terms of trade multiplied by export volume; it may also be expressed as the current dollar values of exports deflated by the dollar prices of imports. Other researchers have obtained mediocre results trying to explain separately the terms of trade and export volume; so did I. Doubts about the quality of the separate indexes strengthen the case for making the purchasing power of exports the variable to be analyzed, even though this variable is far from ideal. ${ }^{26}$

Another controversial aspect of the Cline estimates involved the extent to which increasing geographic diversification of Latin American export markets before 1982 biased the estimates for export elasticity with respect to growth in OECD countries. I tried regressions (not shown) in which the independent variable was the average share of a country's exports going to OECD countries during the previous three

26. OPEC actions, not represented in the regressions, will influence both industrial country growth and the terms of trade of oil importers and oil exporters in Latin America, generating spurious correlations of unknown size. The length of the period covered in the regressions offers modest reassurance on this point. 
years. The estimated coefficients were negative for Argentina, Brazil, Chile, and Colombia, but had $t$-statistics no higher than 1.3. For Mexico and Venezuela, $t$-statistics were greater than 2.1, but the coefficient for the OECD countries' lagged share in exports was positive. For Argentina, Brazil, Chile, and Colombia, the introduction of this variable in the regressions raised the coefficient for GNP growth in OECD countries. Pending more-disaggregated export functions (OECD versus the rest), the results of table 13 appear preferable to those using ad hoc dummies. An exploration of the independent impact of real dollar interest rates on the purchasing power of Latin American exports, operating presumably via the terms of trade and separately from changes in OECD GNP, also yielded insignificant results.

The elasticity of exports with respect to contemporaneous OECD growth is in the range of 2.6 to 3.7 for non-oil countries not heavily reliant on coffee. This surprisingly high elasticity includes volume effects as well as terms of trade effects of OECD growth on exports. The acceleration of OECD GNP during the previous year (that is, the difference in the OECD growth rate between $t-2$ and $t-1$ ) also registers significant coefficients for Argentina and Chile. The regressions for Mexico and Venezuela show that when OECD growth declines, the purchasing power of Mexican and Venezuelan exports increases. Given conditions in the oil market, the specification in these equations is highly questionable, because causation is likely to be opposite to that implied by the regressions.

Real exchange rate changes, lagged one year to avoid simultaneity problems, among other reasons, influence export performance in Brazil, Chile, and less clearly in Argentina. There are, of course, other exportpromotion policies not reflected in the real exchange rate, and there are other definitions for the real exchange rate, such as those using wages as deflators, which may yield better results. The results for Colombia are disappointing; other studies have yielded significant coefficients for the effective exchange rate variable when nontraditional exports were examined separately. ${ }^{27}$ For the case of Brazil, the coefficient for the

27. See Carlos F. Diaz-Alejandro, Foreign Trade Regimes and Economic Development: Colombia (New York: Columbia University Press, 1976), especially chap. 2. For a more recent study, also showing the responsiveness of the supply of Colombian nontraditional exports to incentives, see Leonardo Villar G., "Determinantes de la evolución de las exportaciones menores en Colombia, 1960-1981," paper prepared for the 1984 Latin American Regional Meeting of the Econometric Society. 
lagged exchange rate reaches a $t$-statistic higher than 4 when the change in the export volume is made the dependent variable, although the coefficient for the contemporaneous exchange rate change is nil.

Intercepts appear related to the trend in the terms of trade; those for Mexico and Venezuela are positive, and all others are negative. Although the results are far from spectacular and call for more disaggregated research, they confirm the importance of expansion in OECD countries for Latin American export recovery. While data and methodology are too shaky to forcefully assert specific estimates, table 13 indicates an elasticity substantially greater than 1 between the purchasing power of exports and OECD growth at least for Argentina, Brazil, and Chile. The results also indicate a more transient but important influence of exchange rate policy on exports. The concern remains, however, that under the conditions of the early 1980s, across-the-board devaluations could have harmful effects on the terms of trade; this suggests that optimum policies would combine devaluations and selective export taxes. Last, there is no assurance that the post-1982 recovery in OECD countries will on average raise Latin American exports as much as previous recoveries did. In the countries under study, 1983 dollar merchandise exports rose weakly or not at all, but preliminary data for the first half of 1984 present a more optimistic picture.

THE REAL EXCHANGE RATE

As a relative price, the real exchange rate can be expected to depend on other relative prices and real factors. In particular, the equilibrium real exchange rate under Latin American conditions is likely to be significantly influenced by permanent and even temporary changes in the external terms of trade (including the world real interest rate) and in international capital flows; the rate should also be affected by changes in the level of protection and, at least temporarily, by domestic policies of various sorts.

Earlier experiments gave encouraging results on the link between terms of trade, regarded as exogenously given to Latin American economies, and the observed real exchange rate. ${ }^{28}$ Table 14 continues

28. Carlos F. Diaz-Alejandro, "Some Historical Vicissitudes of Open Economies in Latin America," in Richard N. Cooper and others, eds., The International Monetary System Under Flexible Exchange Rates-Global, Regional, and National: Essays in Honor of Robert Triffin (Ballinger, 1982), especially table 11-6, p. 180. A more detailed 
Table 14. Regressions for Real Exchange Rates ${ }^{a}$

\begin{tabular}{|c|c|c|c|c|c|c|}
\hline $\begin{array}{l}\text { Independent } \\
\text { variable }\end{array}$ & Argentina & Brazil & Chile & Colombia & Mexico & Venezuela \\
\hline Intercept & $\begin{array}{c}4.83 \\
(1.89)\end{array}$ & $\begin{array}{c}6.05 \\
(5.47)\end{array}$ & $\begin{array}{l}11.54 \\
(2.66)\end{array}$ & $\begin{array}{c}7.28 \\
(4.85)\end{array}$ & $\begin{array}{c}9.97 \\
(10.50)\end{array}$ & $\begin{array}{c}4.21 \\
(7.84)\end{array}$ \\
\hline $\begin{array}{l}\text { ln of terms } \\
\text { of trade }\end{array}$ & $\begin{array}{l}-0.36 \\
(-0.81)\end{array}$ & $\begin{array}{l}-0.30 \\
(-1.95)\end{array}$ & $\begin{array}{l}-0.76 \\
(-2.37)\end{array}$ & $\begin{array}{l}-0.56 \\
(-3.22)\end{array}$ & $\begin{array}{l}-0.43 \\
(-3.68)\end{array}$ & $\begin{array}{l}-0.03 \\
(-0.42)\end{array}$ \\
\hline $\begin{array}{l}\text { In of imports } \\
\text { over exports, } \\
\text { lagged }\end{array}$ & $\begin{array}{c}0.25 \\
(0.76)\end{array}$ & $\begin{array}{l}-0.05 \\
(-0.26)\end{array}$ & $\begin{array}{c}-0.92 \\
(-1.17)\end{array}$ & $\begin{array}{l}-0.13 \\
(-0.54)\end{array}$ & $\begin{array}{l}-0.64 \\
(-4.87)\end{array}$ & $\begin{array}{c}0.12 \\
(1.04)\end{array}$ \\
\hline Maxi dummy & $\begin{array}{c}0.28 \\
(3.75)\end{array}$ & $\begin{array}{c}0.15 \\
(3.24)\end{array}$ & $\begin{array}{c}0.18 \\
(1.45)\end{array}$ & $\begin{array}{c}0.09 \\
(1.73)\end{array}$ & $\begin{array}{c}0.23 \\
(6.19)\end{array}$ & $\begin{array}{c}0.18 \\
(2.98)\end{array}$ \\
\hline $\begin{array}{l}\text { Maxi dummy, } \\
\text { lagged }\end{array}$ & $\begin{array}{c}0.17 \\
(2.20)\end{array}$ & $\begin{array}{c}0.09 \\
(1.74)\end{array}$ & $\begin{array}{c}0.23 \\
(2.13)\end{array}$ & $\begin{array}{c}0.06 \\
(1.12)\end{array}$ & $\begin{array}{c}0.20 \\
(5.51)\end{array}$ & $\begin{array}{c}0.08 \\
(1.35)\end{array}$ \\
\hline Trend & $\ldots$ & $\ldots$ & . . & $\begin{array}{r}0.025 \\
(5.34)\end{array}$ & $\ldots$ & $\ldots$ \\
\hline \multicolumn{7}{|l|}{ Summary statistic } \\
\hline $\begin{array}{l}\bar{R}^{2} \\
\text { Autoregressive }\end{array}$ & 0.39 & 0.54 & 0.37 & 0.63 & 0.79 & 0.36 \\
\hline $\begin{array}{l}\text { parameter } \\
\text { Degrees }\end{array}$ & -0.65 & -0.54 & -0.65 & -0.57 & -0.50 & -0.74 \\
\hline of freedom & 27 & 17 & 17 & 25 & 17 & 17 \\
\hline
\end{tabular}

Source: Real dollar exchange rates, as in table 1. Data on terms of trade, U.N. Economic Commission for Latin America. Import and export data, IMF, International Financial Statistics, Yearbook 1983. Independent variables, see text.

a. Dependent variable is the natural log of the real exchange rate. Annual data. Maxi dummies took values of 1.0 as follows: Argentina: 1956, 1959, 1962, 1972, 1975, 1981, and 1982. Brazil: 1964, 1979, 1980, 1983. Chile: 1963, 1973, 1974, 1982, 1983. Colombia: 1957, 1958, 1963, 1966. Mexico: 1976, 1977, 1982. Venezuela: 1964.

some of these experiments and gives the "best" results for each country by using data for each country as far back as they seemed reliable. Examination of the data on terms of trade showed a close, positive correlation between those for a given year and those for the previous year; the $\bar{R}^{2}$ ranged from 0.4 to 0.9 . The terms of trade variable used in table 14 is therefore the logarithm of the simple average for the contemporaneous and the lagged (by one year) terms of trade. As a proxy for capital flows, which are assumed to be supply-constrained, the average

study for Argentina is found in Carlos F. Diaz-Alejandro, "Exchange Rates and Terms of Trade in the Argentine Republic, 1913-1976," in Moshé Syrquin and Simón Teitel, eds., Trade, Stability, Technology and Equity in Latin America (Academic Press, 1982), pp. $27-41$. 
ratio of merchandise imports over exports for years $t-1, t-2$, and $t-3$ was included as another independent variable. Clearly, this variable could also be picking up reserve losses (signaling not appreciation but impending devaluation) as well as growth differentials between the home country and the rest of the world. Measurement difficulties impeded the inclusion of commercial policy variables as a third real influence on the real exchange rate.

Can policy actions, especially via large and presumably unexpected nominal devaluations, affect the real exchange rate? Many thought not during the late 1970s in Latin America's Southern Cone countries. To test the proposition, I concocted for each country "maxi dummies" having a value of 1 when large nominal devaluations occurred and 0 otherwise. "Large" devaluations were defined relative to previous and following years and relative to average nominal devaluations for each country. When devaluations occurred very late in a given year, they were assigned to the following year. Maxi dummies were concocted after obtaining mixed results with other nominal policy variables such as the acceleration of monetary expansion. ${ }^{29}$

The regressions estimated in table 14 combine real and policy variables in an admittedly ad hoc fashion and without exploring their interaction; these facts plus the use of annual data limit claims that the regressions would predict the true equilibrium real exchange rates for each country. Nevertheless, a number of conclusions may be drawn from them. Excepting Argentina and Venezuela, terms of trade show a significant influence on the real exchange rate. In Venezuela during the period under study, very ample exchange reserves weakened the expected link between those two variables, while in Argentina that link may have been swamped by volatility in other real and policy variables. Only the regression for Mexico shows a significant coefficient for the capital flow proxy variable.

The maxi dummies, on the other hand, do remarkably well, often stealing significance from the other variables. Interestingly, the maxi dummies do poorly in Colombia, where a badly managed maxi devaluation in 1962-63 paved the way for the adoption in 1967 of a crawling peg; since then Colombia has avoided maxi devaluations. (Colombia is

29. An interesting attempt to model abrupt exchange rate adjustments can be found in David E. Yuravlivker, "Political Shocks, International Reserves and the Real Exchange Rate, Argentina, 1970s"' (Washington, D.C.: World Bank, 1984). 
also the only country whose real exchange rate shows a positive trend stretching back to the 1950s.) On the whole the dummies leave little doubt that maxi nominal devaluations can increase the real exchange rate contemporaneously and with a one-year lag. Taken literally, the regressions of table 14 indicate that the maxis can engineer permanent changes in the real exchange rate (that is, no negative lagged coefficients were obtained).

The poor results obtained with the proxy variable for capital flow led to further experimentation by using the U.S. real interest rate ex post; the expectation was that the higher that rate, the more depreciated the Latin American exchange rates would be. Only the regressions for Brazil and, again, Mexico yielded interesting results (not shown). The Brazilian results are not robust with respect to different specifications. The Mexican results, on the other hand, are remarkably good.

Table 14 combined with tables 11,12 , and 13 suggests that the dynamic interactions among terms of trade, exchange rates, and trade flows can become quite complex even when taking the terms of trade as exogenous. Terms of trade and capital flows will influence the real exchange rate, which in turn will affect imports and exports. Lags in these interactions could confuse the policymaker who does not have a reasonable estimate of "permanent" terms of trade and capital flows and of their structural links with the "equilibrium" real exchange rate. Without such an estimate it is impossible to evaluate whether a maxi devaluation is needed to bring the real exchange rate to its equilibrium level. Table 14 provides far from all of the necessary guidelines, but together with the small 1983 error terms in its regressions, not shown, it has qualitative implications: it indicates that if 1983 terms of trade and capital flows are assumed to be permanent, then the 1983 real exchange rates were about right, in the sense of being compatible with the hypothesis underlying table 14 . The debatable exceptions to this may be Colombia and Venezuela. During the first half of 1984 the Venezuelan real exchange rate depreciated significantly; Colombia accelerated her mini devaluations, also raising her real exchange rate.

\section{Some Reflections on the Land of $\mathrm{Oz}$ and a Look at the Future}

In this final section I first explore more fully the issue of capital flight from Latin America during the crisis. I then review the considerations 
that many a Latin American president must have faced in deciding whether to service the external debt and the related issue of whether to sign a standby agreement with the IMF. Whatever was expected by the countries undergoing adjustment, I show that the rewards offered by the international system to these countries thus far have been meager. I close with some modest proposals for international action. ${ }^{30}$

\section{PUBLIC DEBT, PRIVATE ASSETS}

Faced with unusual economic and political uncertainties, Latin American middle and upper classes have traditionally diversified their portfolios, placing some of their wealth in Miami, New York, London, Zurich, and even Montevideo and Panama. Frequently in such cases money has been deposited in the same foreign banks that are lending to home country firms and governments. Such "exportation of financial intermediation" has been common particularly in Central America and the Caribbean at least since the beginning of this century. Internationalized households would also prefer to buy government bonds, denominated in foreign currency, in London or New York rather than locally.

Historically the net portfolio share held abroad, perhaps one-tenth, has been considered compatible with a socioeconomic system of tolerable legitimacy; the share held abroad appears to have risen sharply since around 1981, especially in Argentina, Chile, Mexico, and Venezuela. For some groups it may have gone above 100 percent; when subsets of households are consolidated with firms they have owned, one may find liabilities at home and assets abroad. The following domestic policies all combined to generate enormous incentives to place household wealth abroad: overvalued exchange rates that could not be expected to last, government subsidization of external borrowing, cheap public loans to domestic firms, company laws with lax equity requirements and clumsy bankruptcy provisions, and unrestricted convertibility. Eager to buttress overvalued exchange rates, some governments guaranteed future access to cheap foreign exchange to firms borrowing abroad, or themselves borrowed abroad to relieve pressure on reserves. Even as some entrepreneurs borrowed heavily for their firms, either in local currency or in dollars with central bank promises of cheap dollars for repayment, they quietly placed their private household wealth abroad.

30. Such a discussion can be found in Diaz-Alejandro, "Good-Bye Financial Repression." 
One may conjecture that such behavior would not be tolerated in Korea and Taiwan.

As was seen earlier, when the crisis came with sharp real devaluations and the cessation of external lending, governments faced a classic dilemma. Textbook rules of the game would have indicated bankruptcy proceedings for firms unable to service debts; presumably new domestic and foreign entrepreneurs would have put existing physical assets to work under new management. Domestic financial intermediaries that had lent to bankrupt firms or had guaranteed their external borrowings might also have to undergo bankruptcy proceedings; the domestic lender of last resort would have to guard against a generalized panic and perhaps also against a wholesale takeover of domestic banks by foreign ones, as happened in Cuba during the 1920-21 crisis.

The textbook solution never had a chance; that this was known ex ante by major actors is the reason that domestic firms relied heavily on debt and that entrepreneurs placed as little as possible of their own money into firms. Arguing the need to save the private sector, maintain employment, and avoid the wholesale takeover by multinational banks and corporations of the country's assets, governments stepped in. In some cases the rhetoric of intervention had a radical cast, as in the Mexican 1982 " "nationalization" of the banking system; in others, as in the Chilean "interventions" of early 1983, the rhetoric was paradoxically laissez faire. The substance of intervention was quite similar even as the rhetoric and instruments varied. By 1984 most of the private external debt had been socialized (as in Chile), or its servicing was being subsidized via special exchange rates, repayment schedules, or tax concessions (as in almost all countries). Much of the domestic private debt had also been socialized or liquified by inflation accompanied by controls, as in Argentina. ${ }^{31}$

The private assets abroad, however, have remained strictly private. Public debt is public in that it is both the responsibility of the state and highly publicized. Private assets belong mostly to households and are

31. The remarkable Chilean case has been analyzed in detail in José Pablo Arellano, "De la liberalización a la intervención: El Mercado de Capitales en Chile 1974-83," Colección Estudios CIEPLAN 11 (Santiago, Chile: CIEPLAN, 1983), and in Arellano, "La difícil salida al Problema del Endeudamiento Interno," Colección Estudios CIEPLAN 13 (1984). The Argentine case is discussed by Roberto Frenkel, "Notas para una investigación sobre el sistema financiero en Argentina" (Buenos Aires: CEDES, 1984), and by Roque B. Fernández, "La Crisis Financiera Argentina: 1980-1982," Desarrollo Económico (Buenos Aires), vol. 23 (April-June 1983), pp. 79-97. 
surrounded by secrecy; the income they generate is frequently exempt from taxes. This situation reduces the political legitimacy of efforts to service the external debt; indeed, it has generated a crisis of legitimacy for the role of the private sector in Latin American development.

The international system as it stands circa 1984 has encouraged the erosion of legitimacy of a mixed economic system in Latin America, and not just by offering extravagant real interest rates, safety, and numerous tax havens. Pressures were brought upon countries to socialize private external debt ex post and to support private local firms with debts abroad. External debts of all sorts have increasingly been brought into the definition of the debt of nations with the presumption that all debt, public or private, is the responsibility of the whole country and of the current government whether or not that regime had anything to do with those contracts and whether or not those contracts were legal.

An orchestrated chorus of banks, governments of OECD countries, and international organizations is increasingly publicizing the debt and broadening its definition while the secrecy of the liabilities of corporations and financial intermediaries in OECD countries is fiercely maintained. (There are exceptions: the U.S. government succeeded in breaching the secrecy of Cayman Islands banks while pursuing an investigation of drug traffic. The British were annoyed.) Foreign banks will not report to Latin American governments even the interest earnings of Latin American residents; U.S. banks will not withhold taxes on interest when depositors give a non-U.S. address. Both capital flight and tax evasion by foreigners are openly encouraged by private and public actors in OECD countries. During 1984 there were reports that U.S. banks were engaged in high-powered campaigns to sell their certificates of deposit in several Latin American countries. The U.S. Treasury has announced plans to sell securities to foreign investors, who will not have to reveal their names; new regulations will also allow U.S. corporations to sell bearer bonds overseas without resorting to offshore subsidiaries, and securities concerns hope to sell to overseas investors bearer bonds backed by U.S. Treasury bonds. ${ }^{32}$ Behavior not permitted to domestic citizens is encouraged among foreigners.

Increasingly, the international system offers Latin American middle

32. See Alan Murray and Michael R. Sesit, "Treasury Issues to Give Secrecy to Foreigners," Wall Street Journal, August 17, 1984, p. 3. On the breaching of the secrecy of the Cayman Islands' banks, see Jo Thomas, "Islands' Bank Secrecy Is Lifted for U.S.," New York Times, July 27, 1984, p. A3. 
and upper classes comfortable possibilities for capital and personal exit, decreasing their incentives for expressing their voice in local affairs, and eroding their loyalty to the state, which nevertheless is expected by the OECD countries to collect taxes to service debt and to provide a suitable climate for investment, trade, and governance. Purely national circuits for transferring savings into investments are undermined: few local entrepreneurs will undertake significant investments without public guarantees and the participation of a foreign "godfather," whether a transnational enterprise or an international financial institution. Domestic savers will prefer to bank and place financial wealth abroad, wealth which may or may not return to the home country via foreign intermediaries drawing on those savings. Internationalized citizens benefit from the high interest on their bank accounts while their less mobile fellow residents complain about usury. All this seems like a new stance for overcoming the uncertainties of underdevelopment and erratic governments but one which seems vulnerable to nationalist fury and to the anger of the majority without wealth abroad. It appears that institutions in this Latin American setting become weaker the more public they are: internationalized households do relatively well and incorporated firms less so, while public sectors, presumably representing all households, are in a shambles.

\section{THE ZIMBABWE APPROACH, OR THE COSTS AND BENEFITS OF ACTIVE OR PASSIVE DEFAULT}

In recent years the new Zimbabwian government inherited a large public debt, much of it to South Africa. Zimbabwe argued that funds taken out of the country on private account had found their way to South Africa and demanded their return. It noted that Zimbabwe could not only default on its public debt but could also take over substantial South African direct investment in Zimbabwe. South Africa blinked. ${ }^{33}$ Such a negotiation is remote from Latin American circumstances, but it is a helpful reminder of the variety of bargaining chips involved when a government considers whether to default and, if so, whether to do it with a repudiation flourish or passively with a creeping accumulation of arrears.

33. This is a crude summary and interpretation of information reported in the Financial Gazette (Johannesburg), March 30, 1984. 
Consider the calculations of a moderate president of a hypothetical large Latin American debtor. The benefits of maintaining reasonably punctual interest payments include the hope of fresh funds from the private banking system, the international institutions, and the governments of OECD countries and their export promotion agencies. Local businessmen, particularly those with extensive international links, will breathe easier and may invest more at home and less abroad. Unimpeded access to the markets, direct investments, and technology of OECD members are other pluses. (Note that even Cuba has maintained interest payments to banks in non-U.S. OECD countries. It has rescheduled its debt to those banks and those countries, interestingly without being pressed to reach agreement with the IMF, to which Cuba does not belong.) The costs of continued debt service include squeezing growth to generate the necessary trade surpluses, which cuts real absorption and wages. Employment may suffer even as real wages are cut.

The benefits of default, besides the suspension of interest payments abroad, could include the seizure of direct foreign investment within the country. Payment of principal could be postponed indefinitely, and tiresome rescheduling sessions could be avoided. The costs of default (which for smaller countries could be very high) include the possible denial by OECD member countries of their markets, technology, and portfolio and direct investment. In the short run the loss of short-term trade credits would be especially painful. It could be that not all OECD countries would impose such embargoes (note again the Cuban case), so the calculation must include probabilities regarding OECD solidarity. To a moderate leader the political consequences of default present a mixed picture. For a while, the leader may bask in nationalist glory, but the forces unleashed by default, especially an active one, may threaten constitutional order and could reopen the gates to populist-nationalist authoritarian generals-after all, the nation would be surrounded by enemies.

Many intermediate solutions are possible, and the moderate president may hope to bargain for a better deal without open default. The president knows that although neither open nor creeping default is likely to bring financial disaster to OECD countries, either type of default would place OECD governments in the politically uncomfortable position of having to rescue two, three, or more major banks. OECD monetary targets may have to be busted during the rescue. The president knows that bargainers 
from OECD countries are aware that the president knows all this. The bargaining situation will also be influenced by the possibility that, while no major debtor country wants to be the first to break openly with the international creditors, once the ice is broken others may join. On the other hand, a "Malvinas syndrome" may reduce the urge to make a bold move leading to lonely disaster.

The decision whether to sign a standby agreement with the IMF involves considerations similar to those surrounding default. Only countries with plentiful reserves or socialist revolutions or without much need for fresh, net loans will indulge in the political luxury of maintaining punctual debt servicing, adopting stiff stabilization plans, and doing without the formal blessing of the IMF. Much of the home business sector, even with punctual servicing of the external debt, may feel vulnerable without the reassurance that the IMF is supervising their country's financial leaders. Political leaders, on the other hand, may hope that once the crisis is over and international reserves rise, they will be able to use "creative accounting" to nibble away at the agreement with the IMF.

A last, delicate consideration will influence the bargaining climate as well as the eagerness of Latin American governments to tax earnings of Latin American private wealth held abroad. (No Latin American government, as far as I know, has pressed tax authorities in OECD countries for the relevant information.) Unlike in Zimbabwe, many people in the moderate regime (or their aunts and cousins) will hold private assets abroad or enjoy substantial contacts with OECD actors. The prospects of being cut off from their bankers abroad, or even from Disneyland, will make many members of the elite pause before risking near anarchy. Imagine the turmoil if the OECD countries threatened to publicize the names of Latin American citizens holding more than $\$ 100,000$ worth of bank deposits, real estate, and other wealth within OECD nations.

The default question during the $1980 \mathrm{~s}$ is quite different from that of the 1930s. Rather than facing scattered bondholders, Latin American countries face a handful of banks that not only lend long but also dispense short-term trade credit and hold a good share of the countries' international reserves. Rather than facing a depressed, divided, and demoralized North, with its own financial system in crisis, Latin America faces a euphoric United States. Rather than facing lame-duck Hoover and goodneighbor Roosevelt, Latin America faces Reagan. 


\section{SYSTEMIC REWARDS TO ADJUSTMENT: A CLOSER LOOK}

An observer from Mars would have been puzzled by the system's 1982-83 record of rewards for "good behavior" with respect to debt service. As noted earlier, the flows of fresh money were exiguous, and no consoling initiatives were forthcoming in trade, technology, or related areas. The OECD countries appeared to take the position that austere adjustment was its own reward or that fear of retaliation should be enough to maintain the punctual observance of contracts made obsolete by changes in the international economy.

Until the rescheduling of Mexican debt in August 1984, the international credit consortium had few carrots to dispense to the well behaved. A careful study of the 1982-83 terms granted in the first series of external debt reschedulings for nine Latin American countries found two features of note: one is the similarity of the terms agreed upon with the various borrowers, and the second is the deterioration of the terms of indebtedness. The negotiated cost of the 1982-83 credits, taking into account spreads, commissions, and amortization periods, represented for Mexico an increase of more than 180 percent over the terms prevailing during $1980-81 .^{34}$

During this process, the hapless IMF has been a bit like the Wizard of Oz: a mythologized contraption through which weak human beings speak. Resources available to the IMF have paled relative to the crisis. Also, probably too much has been made of IMF policies and procedures during the last few years: like the Federal Reserve Board, the IMF follows election results, and it could have been singing a different tune had Jimmy Carter been reelected. Indeed, during 1979-80 the IMF gave every indication of adapting to a Carter-Callaghan view of economic policy. ${ }^{35}$ Even if the IMF became convinced of the need for stretching out adjustment in Latin American countries, it is doubtful that with the resources at its disposal it could do anything without a change of attitude in the U.S. administration and Congress. Other multilateral institutions such as the World Bank and the Inter-American Bank have also been

34. See U.N. Economic Commission for Latin America, Adjustment Policies, pp. 60-63.

35. To recapture the pre-November 1980 mood, now so distant, see "Is the IMF Growing a Softer Heart, or Just a Softer Head?' Economist (October 4-8, 1980), pp. 67-70. 
under pressure from the U.S. Treasury (and the U.S. Republican party platform) since 1980, and their capacity for autonomous action is very limited. International private banks cannot do much on their own, needing the approval not only of their supervisors but also of legislatures.

A serious flaw in the 1982-83 structure of systemic incentives to adjustment and debt servicing was the uncertain link between domestic austerity and foreign exchange payoff. A government, in spite of draconian measures, could fail to meet its foreign exchange targets owing to a sudden increase in interest rates abroad, an unexpected fall in the international price of its exports, or a tantrum by a regional U.S. bank or U.S. populist leader. Politicians and technocrats putting their political lives on the line to support austere adjustment could be wiped out by exogenous events which no one understands and whose rationality is moot. The lack of safety nets that would deal with such events and reassure bold adjusters is curious from the international system's own viewpoint.

The Mexican rescheduling of August 1984 may open new vistas that are not yet visible. Perhaps there are additional secret reassurances to the well behaved that are not publicly revealed for political or moralhazard reasons; perhaps there are secret plans to be enacted after November 1984 to stretch out repayment schedules and to reduce interest and fees for many countries. As to growth, if a credible promise cannot be made to support economic expansion among the debtors, at least insurance against a worsening situation could be provided.

\section{A REVIEW OF SCENARIOS}

Forecasting the balance of payments for Latin American countries has become a major indoor sport among bankers, bureaucrats, and academics. Yet even among those most outspoken about the excesses of Latin American inflation, public expenditures, and budget deficits, little or no attention is paid to the connection between foreign exchange supplies and these excesses; when it comes to deciding whether or not interest payments will be forthcoming, attention will focus almost exclusively on the balance of payments. References to inflation and budget deficits are typically left to final, exhortative paragraphs. It seems as if the IMF targets or objectives in the fiscal and macroeconomic areas are meant less as reasoned forecasts of what is compatible with projected 
foreign exchange availabilities than as overambitious goals to make sure that, if policy errors are to be made, they will be made on the side of too much rather than too little restrictiveness. Overkill in macroeconomic policy fattens the trade surplus. This could explain why the 1983-84 stabilization plans adopted under IMF sponsorship have been so successful in meeting trade surplus objectives while overshooting their own inflation projections and undershooting their growth projections. The inflation and growth estimates were known at the outset to be unrealistic. It is often argued that the important thing is not whether forecasts of inflation or growth are met but to have an IMF standby agreement and "process," meaning that what counts is the trade surplus. The new Argentine government, coming to power after many years of official lies, had trouble accepting such misleading stabilization programs, and apparently this was one of the stumbling blocks in their negotiations with the IMF. The Brazilian military regime, on the other hand, seems almost to have relished signing unrealistic letters of intent; since December 1982 it has signed four of them.

There are few mysteries in the mechanics of balance of payments forecasts available for major Latin American countries. The same crucial variables and coefficients can be found in all of them: growth in OECD countries and the induced growth of Latin American exports, the real international interest rate, net new "involuntary" or "concerted" lending by private banks, and direct foreign investment. Real exchange rates and what they can do to push exports further are usually the major domestic policy variable taken into account. Policy-induced declines in oil imports are sometimes featured. Non-oil imports and the growth allowed by them are the residuals. Most forecasters seem to regard projections of unemployment ${ }^{36}$ and real wages to be in bad taste, and even fewer dare to provide their best estimates of inflation and budget deficits.

The thrust of these projections is easily summarized. Plausible growth in OECD countries (without new protectionism) combined with interest rate declines, some fresh lending, and domestic export promotion will

36. In countries like Brazil and Mexico, birth rates are declining. But growth in the potential labor force still reflects birth rates of twenty years ago. According to the U.N. Economic Commission for Latin America, the growth in Brazilian population was 3.0 percent per year during $1960-65$ and is expected to be 2.2 percent during $1980-85$. For Mexico, the corresponding figures are 3.4 and 2.7. 
sharply reduce ratios of debt to exports and improve creditworthiness almost everywhere in a couple of years or so. Under these circumstances, Latin American growth could pick up slowly, and by 1990 the per capita incomes achieved in 1980 could be reached again. Interestingly, few forecasters dare to paint scenarios more optimistic than this for Latin American GDP. Few projections imply that net new lending will exceed interest payments during the next three or four years. Some hope for favorable random shocks-such as frosts and citrus canker in Florida or oil discoveries-is sometimes offered.

There are problems with "optimistic" projections contemplating Latin American trade surpluses for the foreseeable future, particularly when those surpluses approach or exceed interest payments. ${ }^{37}$ Their political sustainability is doubtful in capital-hungry countries expected to generate a persistent resource transfer abroad. Moreover, in a context of reasonably free financial markets, such projections are in the nature of self-destroying prophecies, at least on the supply side. For example, if all bankers were really to believe that Brazil will be generating trade surpluses of $\$ 15$ billion by the end of the decade, a veritable stampede toward Brasília would occur. Brazilians would again be swamped with loan offers and, if Brazilians accepted the loans, those trade surpluses would not materialize. Trade surpluses of $\$ 15$ billion in Brazil by the end of the decade would require not only remarkable political developments within that country but a permanent international credit consortium that would switch from promoting to curtailing international lending. Persistently high real interest rates would reduce the demand for new loans but would also reduce the willingness to squeeze absorption for the sake of generating trade surpluses.

The optimistic scenarios do reflect the fact that substantial external adjustment has occurred, particularly in Brazil, Chile, Mexico, and Venezuela, and that expected balance of payments conditions in those countries provide some room to grow or to substantially improve debt indicators. In Argentina, Brazil, and Mexico inflation loomed as more of an immediate problem for 1984 than external debt and the balance of

37. For one such projection for Brazil see Morgan Guaranty Trust Company, World Financial Markets (July 1984). This study concludes that "even on a conservative assessment it seems realistic to envisage Brazil's trade surplus edging higher from the present level of $\$ 10-\$ 12$ billion to perhaps $\$ 15$ billion by the end of the decade. This would shrink the current account deficit to about $\$ 3$ billion per annum on average, and quite possibly less at least in some years"' (p. 11). 
payments. Indeed, the improvement in the payments situation and the increase in international reserves in well-behaved Brazil and Mexico hint at a tougher negotiating stance by these countries in the near future. The buildup of Brazilian and Mexican reserves has not produced unrestrained glee among all lenders.

The optimistic scenario could be upset by international recession in 1985-86, real interest rates remaining at 1982-83 levels, an upsurge of foreign protectionism, or negative or even zero net real lending. Few forecasters go much beyond the gloomy foreign exchange earnings implied by those circumstances. Increases in nominal interest rates and further declines in the prices of some primary products during the first semester of 1984 underlined how brittle the debt situation remains even after more than one year of unexpectedly vigorous U.S. recovery.

There is little doubt that the last few years have witnessed a brilliant political victory for the Reagan-Thatcher camp. In the North-South arena they have, thus far, disciplined the third world and even put OPEC on the defensive while reshaping the multilateral agencies after their own image. Given their agenda and welfare function, they have scored well; the fulfillment of the optimistic scenarios would crown this conservative restoration. Under these circumstances, advice on systemic reform based on a different welfare function is unlikely to get very far. Yet even those in charge of the system in 1984 should be concerned about its vulnerability to bad news and threats to it from those who feel grievously wronged.

Prudent insurance steps would start with the assumption that events of the early 1980s led to capital losses to those who engaged in borrowing and lending during the late 1970s while expecting a different set of events. Both Latin American borrowers and their lenders made mistakes in their forecasts. There is a need to share that loss in a way that is perceived as equitable; also for the sake of the future there is a need to guard against severe bad news, against which private markets provide no insurance.

A modest package of systemic reforms would include the following points:

-Expand IMF resources (which could be borrowed) so that at least the potential for sensible stabilization programs would exist.

-Expand and reform the Compensatory Financing Facility (CFF) to provide partial insurance against unexpected fluctuations in the purchasing power of exports of goods and services (and in doing so, include 
financial charges on the external debt in the price index for imports of goods and services). ${ }^{38}$

-At the expanded CFF, project the purchasing power of exports taking into account not only expected international economic circumstances, but also each country's domestic policies. Export performance, suitably adjusted for unexpected changes in the world economy as well as for supply shocks, could then become the crucial element in "conditionality" for the CFF, the IMF, and other multilateral institutions. ${ }^{39}$ These organizations would also monitor protectionism so as to determine when export targets are not being reached due to restrictive actions by importing countries.

-Through official OECD intervention encourage longer-term restructuring of debt and discourage monopoly pricing and the indiscriminate lumping together of old public and private debts in the rescheduling process.

-Take international action to eliminate tax havens and limit tax evasion on interest earnings (information on earnings by assets held by foreigners would be shared only with governments committed to opposing confiscation of the assets); this international action could be coordinated with efforts to combat drug traffic and other illicit trade. Taxes levied on interest earned by Latin American deposits in foreign banks could be turned over to the Inter-American Development Bank.

- Through the moral suasion of central banks restrain aggressive marketing techniques of private banks promoting capital flight from developing countries.

The biggest systemic challenge remains the phasing out, or at least the true internationalization, of the international credit consortium started in 1982 to deal with the debt crisis. Unlike 1974-75, few would argue in 1984 that the international economic order is in no need of systemic reform, at least in its financial sphere. It is remarkable that

38. For an elaboration of the case for expanding and reforming the CFF see Carlos F. Diaz-Alejandro, "International Markets in the 1980s," Journal of International Affairs, vol. 38 (Summer 1984), pp. 11-20. The CFF currently projects the nominal value of exports and has no provision to cover variations in interest charges. The suggested reform would thus provide insurance against unexpected changes in both contemporaneous and intertemporal terms of trade.

39. This is a variation on a very old idea. See Lester B. Pearson and others, Partners in Development; Report of the Commission on International Development (Praeger, 1969), p. 132. 
even IMF publications describing today's international capital markets use terms such as "herd effect," "contagion effects," "overlending," and "crisis of confidence," which are hardly compatible with wellfunctioning competitive markets. ${ }^{40}$ So far, there are few explicit visions of how a reconstructed international financial market for developing countries would look. But clearly, in a rational system Mexico would not export capital to the United States, as in 1983-84, and Colombiastill a prime candidate for a 1984 bridge loan-would not be subject to the pressures it has received from international banks. (A popular story alleges that banks forced to lend to Brazil and Mexico, but facing selfimposed, arbitrary lending ceilings to Latin America as a whole, simply cut back lending to Colombia.)

It may be well to recall a bit of history. Taking advantage of the weakened Argentine position during the 1930s, the United Kingdom successfully imposed the Roca-Runciman treaties on that country, obtaining especially favorable conditions for British trade and investors, conditions which even cool U.S. observers found outrageous. ${ }^{41}$ Led by able technocrats, Argentine economic policy adjusted; the country managed to maintain punctual servicing of the national external debt and provide foreign exchange for profit remittances abroad. Argentine growth and industrialization even managed to pick up, and by the late 1930s all seemed reasonably well. The nationalist-populist coup of June 1943 , however, was able to revive memories of wounded national pride with notable domestic political success and with disturbing consequences for the international system.

40. Paul Mentré, The Fund, Commercial Banks, and Member Countries, Occasional Paper 26(Washington, D.C.:IMF, April 18, 1984). This paperalso suggests that competition leads to overlending (p. 26) and proposes that "foreign exchange proceeds should be centralized through market transactions or compulsory requirements. There should be a comprehensive system of external debt reporting by individual corporations, banks, and public entities and a system of authorizations or guidelines for borrowing, either by approving individual transactions or by setting ceilings by categories of external debt for each borrowing entity"' (p. 21). This is a long way from the Robichek doctrine.

41. See for example Virgil Salera, Exchange Control and the Argentine Market (New York: Columbia University Press, 1941), p. 89. U.S. exporters, of course, felt the RocaRunciman treaties placed British exporters in an unfairly favorable position. Today U.S. exporters to Latin America, unlike German exporters to Poland, appear to take scant notice of how debt servicing limits their Latin American market, probably confident of the dynamism of their home market. The same could be said about U.S. direct investors in Latin America. 


\section{Comments and Discussion}

Paul R. Krugman: Carlos Diaz-Alejandro's paper is a broad sweep across a complex landscape and is more concerned with providing insight into a variety of issues than with developing any oversimplified set of conclusions. This makes the task of a discussant difficult. What I will do in these comments is to impose on Diaz-Alejandro's paper a schematic structure which probably does violence to his intention but may still be useful for purposes of discussion.

One way to view this paper, then, is as an effort to answer three questions regarding debts of less-developed countries. The first of these is, how did we get here? Was it mismanagement by the debtor countries or an adverse shift in their environment? Or, more generally, what is the mix between these causes? The second question is, how are we doing? Does the success of the IMF, the debtor countries, and the banks in avoiding any outright rupture so far represent real progress toward a solution of the problem, or are we merely papering over an increasingly untenable fundamental position? Third, where do we go from here? Is the current strategy the right one, with perhaps a few marginal modifications called for, or do we need a major rethinking?

How Did We Get Here? A major theme of this paper is the argument that, whatever the sins of debtor nations, they pale in comparison with the external shocks of 1979-82. One interpretation of the paper's unusual title would be to note that while Dorothy really should have had her dog on a leash, basically it was the tornado that was the problem. Similarly, Brazil really should have devalued the real cruzeiro sooner, but it was the combination of world recession and high world real interest rates that pushed it into crisis.

Before I discuss this argument, let me raise a question that Diaz- 
Alejandro does not, namely, so what? Aside from the lessons to be learned from history, why does it matter how we got where we are? The answer, I think, lies in the issue of moral hazard. The current debt strategy involves, de facto, an element of bailout of debtors by their creditors, on one hand, and bailout of both debtors and creditors by official agencies, on the other. If the problems of debtor countries basically reflected irresponsible behavior, such a bailout would provide encouragement for more such behavior in the future. If, on the other hand, the debt crisis can be viewed basically as an act of God (or his earthly manifestation, Paul Volcker), this is not a concern.

What, then, is the evidence presented in this paper for the dominant role of the external shock? It is of three kinds. The paper argues, first, that the economic management of at least some of the problem debtors was not that bad, second, that the external shocks were of overwhelming magnitude, and third, the fact that countries with very different pre-1982 policies all found themselves in similar straits shows the predominance of external factors.

Judging the quality of economic management directly instead of by results is not an easy task. As far as we can judge, some countries, such as Argentina, followed remarkably unsound policies in the late 1970 s and early 1980s. Others, such as Brazil, were sober and apparently realistic. As the paper says, there was undoubtedly something wrong with each country's policy, but an observer in 1980 would not have seen a Latin America-wide pattern of catastrophically bad management.

The second argument-that external shocks were of great importance-is clearly right. However, I am unhappy with the way the case is argued. In the paper the sharp cutback of new lending to debtors in 198283 is treated as an exogenous event-rather as if Robert Shiller had descended from heaven and decreed lending to Latin America suddenly unfashionable. This is just not a satisfactory procedure. If a country were to follow irresponsible policies and lose the confidence of lenders as a result, one would not want to treat the falloff of lending as an exogenous event. I would prefer to regard domestic economic management, the terms of trade, and interest rates as the fundamentals here, and the supply of funds as an endogenous variable. This still supports a view that assigns heavy weight to the external factors, but it does so to a somewhat less dramatic extent than this paper's approach.

Third, the commonality of experience is indeed a powerful argument 
for the dominance of the external shocks. Tough-minded Brazil and Chile fared no better than spendthrift Mexico and wacko Argentina, suggesting that the fault was in their stars rather than themselves.

The moral of this analysis, then, is that irresponsible behavior by debtors did not bring on the crisis, so that we need not worry about creating incentives for future irresponsibility by attempting to manage the crisis.

How Are We Doing? The central fact about the handling of the debt crisis that we need to evaluate is the remarkable movement of LDC trade balances into large surplus. On the face of it this is good news: debtors are showing an ability to adjust their balances of payments, which should be a source of reassurance to their creditors. The question is whether this success is in some sense illusory. Is the favorable trade performance only borrowed at the expense of the future, on one hand, or being purchased at an ultimately unsustainable social cost, on the other?

The paper suggests both conclusions. It argues that trade balance improvements are largely being achieved at the expense of investment and that this will either cripple future growth or require a large import bulge in the future. It also argues that the legitimacy of debtor-country institutions is being radically eroded.

The argument that investment and imports are near-perfect substitutes is a compellingly simple one. What would have been useful here is an accounting exercise, even if it is necessarily speculative: how much of the improvement in trade balances can we attribute to the decline in investment?

Now it may be the case that improved trade balances reflect nothing but investment cuts and recession in debtor countries and that the gains will rapidly vanish when these economies expand. Here again I wish that Diaz-Alejandro had used his econometrics to produce an accounting of sources of trade balance improvement. My own impression, based partly on preliminary work by one of my students, partly on hunch, is that recession is not the whole story. In Mexico, in particular, expenditure switching via the huge real devaluation and exchange controls has probably played an important role even in the events so far and will play an increasingly important role over time.

Finally, there is the question of the sustainability of all this. Economists are nearly as bad at making political forecasts as political scientists are, so I won't venture one. The paper strongly emphasized the impor- 
tance of capital flight for the legitimacy of the debt strategy; I understand that Jeffrey Sachs will have something to say about that, so I gratefully leave it to him.

Where Do We Go from Here? The final question is one of policy. This is not a major theme in the paper, and perhaps could not have been given the paper's other aims. A full discussion of the policy response requires a theoretical basis, and that means a whole other paper. Still, we should say something about the theory and practice of debt strategy.

Over the last few years several authors, including William Cline and Jeffrey Sachs, have developed at least a schematic theory of the role of policy in a debt crisis. The heart of this theory is the argument that in a debt crisis, continued lending is unprofitable for any individual lender because of the risks of future nonpayment, but it is in the collective interest of creditors to lend enough to avert an immediate default. The problem of collective action can be used to justify both involuntary lending by existing creditors and official lending to mitigate the freerider problem. In other words, the theoretical analysis suggests that the current debt strategy of creditor nations makes at least some sense.

Diaz-Alejandro appears to agree. His list of proposed reforms is more a set of marginal changes than a radical rethinking. In fact, I can easily think of some other major sensible changes-for example, telling the IMF to worry less about inflation and budget deficits and to focus its plans more on expenditure switching and less on expenditure reducing.

A final note. I once had occasion to explain the current debt strategy to a largely agribusiness audience in Minnesota. When I had finished, I was informed that what I had described was basically the same as what a local bank does with a farmer in trouble. I'm an Easterner, to whom the whole Midwest is one big blur, so perhaps I can be forgiven for assuming that other states are just like Minnesota in this regard-in other words, for suggesting that we may still be in Kansas after all.

Jeffrey D. Sachs: When Carlos Diaz-Alejandro chose in his title and analogies to place the current international debt crisis in the Land of $\mathrm{Oz}$, he selected an appropriate venue. Few people realize that the original Wizard of $\mathrm{Oz}$ by L. Frank Baum is itself partly an economic parable in which the Wicked Witch of the East represents Eastern capitalists who dehumanize kindly laborers like the Tin Woodman. ${ }^{1}$ The word $O z$ is

1. See H. M. Littlefield, "The Wizard of Oz: Parable on Populism," American Quarterly, vol. 16 (Spring 1964), pp. 47-58. 
probably constructed by one-letter transpositions of NY, the home of those predatory capitalists. Baum, a bemused populist sympathizer at the turn of the century, would delight in Diaz-Alejandro's characterization of the "hapless"' IMF as today's Wizard.

What is harder to judge from the paper is whether Diaz-Alejandro shares the original story's populist sentiments. At places, he does suggest that external shocks from the OECD played the predominant role in the debt crisis. In his context, he blames the Wicked Witch of the North for the economic suffering of the South. In many other places, however, he recognizes that severe self-inflicted wounds have played a major role in the process. In the end, we don't know whether it's the IMF that needs a heart or the Southern Cone dictatorships that need a brain.

The great strength and charm of this paper is indeed its eclectic approach. We sense that Diaz-Alejandro is unwilling to be swept into simplistic arguments about the causes of the debt crisis, and by extension, its resolution. We are titillated with a wide range of ideas and observations that place the source of the crisis primarily in external shocks but also in widespread capital flight, poor exchange rate management, and so on. On the issue of resolving the debt crisis, Diaz-Alejandro is again eclectic and reserved: better exchange rate management in the debtor countries, moderate IMF policies, fast OECD growth, and modest systemic reform all play a role in Diaz-Alejandro's desired process.

Unfortunately, this eclectic approach does not provide a convincing answer to the question that Diaz-Alejandro raises eloquently. How is it that in a group of countries that pursued vastly different policies, a group that includes both oil importers and exporters as well as current account deficit and surplus countries (Venezuela), each country ended up in the same contractionary, debt-ridden condition in 1984? And conversely, how is it that many countries outside of Latin America, faced with the same shocks and loaded with a heavy external burden, have (so far) avoided the crisis?

In the second section of the paper, Diaz-Alejandro stresses a twostage explanation of the debt crisis, focusing heavily on external shocks to the debtor countries. In the first stage (1980-81), the Latin American economies were battered by terms of trade deterioration as a result of higher OPEC prices and a deep recession in the OECD. The reduction in export earnings ushered in the second stage (1982-present), when the Latin American countries were hit by a dramatic cutoff in new bank 
lending. Diaz-Alejandro regards this credit cutoff as prompted by, but not justified by, the worsening terms of trade. In his view, the terms of trade deterioration should have led to a gradual reduction in lending but not the stampede away from new loans that occurred in 1982. His emphasis on the suddenness and "collective irrationality" of the lending cutoff is convincing. Recent theorizing has shown how such "herd behavior" can result from the rational decisions of individual banks. ${ }^{2}$

The main problem with Diaz-Alejandro's two-stage argument is its overemphasis on external shocks and underemphasis on domestic policy mistakes in explaining the Latin American predicament. On one hand, Mexico and Venezuela had huge terms of trade improvements after 1979; and on the other, the developing countries in Asia also suffered terms of trade declines of the magnitude in Latin America without provoking a dire crisis. A comparison is made in my table 1, to which I return several times. The cutoff in lending to Mexico and others in 1982 did not result simply from external shocks or from a bankers' panic. The cutoff arose as much from a remarkable hemorrhaging of dollars from these economies, in the form of capital flight, after 1980. Foreign official borrowing by the Latin American economies supported perhaps $\$ 50-60$ billion of capital flight in 1981-82 alone.

A short digression on the Venezuelan case can make the point most clearly. ${ }^{3}$ From 1974 to 1982 , Venezuela ran a cumulative current account surplus of $\$ 5$ billion. It enjoyed two huge terms of trade gains in the decade during the oil shocks of 1973-74 and 1979-80. By 1981, it had accumulated foreign reserves of $\$ 19$ billion. And yet by 1983, real GNP was falling by 4.7 percent and the government is now renegotiating $\$ 22$ billion of external public debt.

What happened in this case, I believe, highlights what is true for much

2. The main point of this theorizing is that each bank's loan decision is properly affected by the loan decisions of other banks. Since no bank alone can extend all of the credit that Mexico or Brazil needs to stay afloat, it is prudent for each bank to lend new money only if other banks are making new loans as well. Because of this interdependence of the banks' decisions, aggregate bank lending may stop not because the country's position has changed, but because each individual bank believes that all of the other banks have decided to stop lending. The prophecy of a loan cutoff can then become self-fulfilling. For details, see Richard N. Cooper and Jeffrey Sachs, "Foreign Borrowing: The Debtor's Perspective," Working Paper 1427 (National Bureau of Economic Research, August 1984).

3. For a clear exposition of the Venezuelan experience, see Miguel Rodriguez, "La verdad sobre el endeudamiento externo venezolano" (Instituto de Estudios Superiores de Administración, Caracas, 1984). 
of the hemisphere. During 1980-83 the Venezuelan private sector fled the domestic financial system and placed perhaps $\$ 20$ billion of foreign assets in the rest of the world (particularly in U.S. banks and real estate). This was possible because the central bank protected a traditional parity of 4.3 bolivars per U.S. dollar by selling dollars even as reserves were being depleted at a shocking rate in 1981-82. Indeed, the policy obtuseness is staggering: the loss of reserves was praised by the central bank's annual report as a way to restrain domestic money growth and thereby to keep down domestic inflation. By 1983, the private sector owned more than $\$ 20$ billion of foreign assets that had been recycled into the $\$ 26$ billion of Venezuelan public foreign borrowing. When foreign lending to the Venezuelan government ceased in 1983 the economy staggered as did those in the rest of the hemisphere in spite of the offsetting expatriate assets.

What happened in Venezuela also occurred in varying degrees in Argentina, Chile, and Mexico, as Diaz-Alejandro points out throughout the paper. In all these cases, the exchange rate was heavily supported by central bank policies, thereby leading to strong currency overvaluation and expectations of future depreciation. In Argentina and Mexico these expectations translated into a remarkably large capital flight that dramatically intensified the debt problem. As Diaz-Alejandro's table 9 and my table 1 suggest, the capital flight in Mexico alone reached perhaps $\$ 25$ billion from 1981 to mid-1982.

Hayek's concept of competition among currencies is helpful here. ${ }^{4}$ His notion is that alternative currencies and whole financial systems across countries compete with each other based on the stability of purchasing power and real rates of return that they offer. Under a floating exchange rate, the "losers" in this competition depreciate, while under a fixed exchange rate the central banks of the "losing" currencies provide the private sector a vehicle of escape into foreign assets. In 1979, when the U.S. dollar started on the path of sharp appreciation and high interest rates, the ability of the bolivar or Mexican peso to compete successfully with the dollar was greatly undermined. Remarkably, some

4. See, for example, F. von Hayek, "Choice in Currency: A Way to Stop Inflation," Occasional Paper 48 (Institute of Economic Affairs, London, 1976). Of course, Hayek welcomes the currency competition, whereas the discussion in the text points out the dangers to weak-currency countries of inviting such competition through liberalization of the capital account. 
Table 1. Five Latin American Economies Compared with Five Asian Economies, 1979-82

\begin{tabular}{|c|c|c|c|c|c|c|}
\hline Country & $\begin{array}{c}\text { Annual real } \\
\text { GDP } \\
\text { growth, } \\
1981-82 \\
\text { (percent) }\end{array}$ & $\begin{array}{c}\text { Annual } \\
\text { inflation, } \\
1979-82 \\
\text { (percent) }\end{array}$ & $\begin{array}{c}\text { Terms of } \\
\text { trade, } 1982 \\
(1978=100)\end{array}$ & $\begin{array}{c}\text { Annual } \\
\text { current } \\
\text { account, } \\
1979-82 \\
\text { (percent of } \\
\text { GNP) }\end{array}$ & $\begin{array}{c}\text { Real }^{\mathrm{a}} \\
\text { exchange } \\
\text { rate, } \\
1979-81 \\
(1978=100)\end{array}$ & $\begin{array}{c}\text { Apparent } \\
\text { capital } \\
\text { flight, } \\
\text { 1979-82 } \\
\text { (billions of } \\
\text { dollars) }\end{array}$ \\
\hline \multicolumn{7}{|l|}{ Latin America } \\
\hline Argentina & -5.6 & 130.5 & 103 & -2.5 & 153 & 11.4 \\
\hline Brazil & -0.3 & 83.6 & 61 & -5.1 & 83 & 1.1 \\
\hline Chile & -4.8 & 24.1 & 69 & -9.7 & 114 & 0.9 \\
\hline Mexico & 3.6 & 32.0 & 112 & -4.1 & 117 & 27.9 \\
\hline Venezuela & 0.2 & 14.8 & 164 & 2.1 & 108 & 20.9 \\
\hline Average & -1.4 & 57.0 & 102 & -3.9 & 115 & $62.2^{c}$ \\
\hline \multicolumn{7}{|l|}{ Asia } \\
\hline Korea & 6.2 & 18.6 & 87 & -6.4 & 99 & 0.8 \\
\hline Malaysia & 6.4 & 6.4 & 96 & -5.1 & 93 & n.a. \\
\hline Philippines & 3.2 & 14.7 & 76 & -6.4 & 105 & 0.2 \\
\hline Sri Lanka & 5.6 & 16.3 & 39 & -11.4 & 100 & -0.3 \\
\hline Thailand & 5.2 & 11.8 & 73 & -6.1 & 100 & -0.4 \\
\hline Average & 5.3 & 13.6 & 74 & -7.1 & 99 & $0.3^{c}$ \\
\hline
\end{tabular}

Source: Terms of trade, U.N. Economic Commission for Latin America, Economic Survey of Latin America, 1983, forthcoming. Debt, World Bank and Bank for International Settlements. Other data, IMF, International Financial Statistics.

a. The real exchange rate is calculated as $E P^{*} / P$, where $E$ is the nominal exchange rate in units of currency per U.S. dollar, $P^{*}$ is the U.S. consumer price index, and $P$ is the local-currency CPI.

b. Computed as follows: apparent capital flight equals observed increase in external debt (public plus private), minus the increase in official foreign exchange revenues, minus the current account deficit (cumulative), plus the cumulative net inflow of foreign direct investment.

c. Total.

countries, such as Argentina, Chile, and Mexico, actually eased capital controls at this time, making the competition even harsher. Not surprisingly, fixed exchange rates proved untenable in countries with high inherited inflation, large budget deficits, and weak financial sectors. By 1981-82, the private banking sectors in Argentina, Chile, and Mexico were largely insolvent.

The Asian economies listed in my table 1 avoided the worst excesses of "competition" with the U.S. dollar for several reasons. In all cases the exchange rate was repeatedly devalued or allowed to float downward to prevent an overvaluation of the real exchange rate. In general, free convertibility in U.S. dollars was blocked by capital controls. And the economies all had a background of lower trend inflation, which made locally denominated assets at least adequate stores of value. In the end, none of the economies evidences any significant degree of capital flight. ${ }^{5}$

5. There has apparently been substantial capital flight from the Philippines in the past year, prompted in part by the political climate following the Aquino assassination. 
Table 2. External Assets and Liabilities of U.S. Banks

Billions of U.S. dollars

\begin{tabular}{lrrr}
\hline Region & 1978 & 1983 & Change \\
\hline Latin America and Caribbean & & & \\
$\quad$ Claims on foreigners & 57.6 & 188.9 & 131.3 \\
Liabilities to foreigners & 31.6 & 114.1 & 82.5 \\
$\quad$ Net & 26.0 & 74.8 & 48.8 \\
Asia & & & \\
Claims on foreigners & 22.2 & 62.7 & 40.5 \\
Liabilities to foreigners & 29.0 & 45.4 & 16.4 \\
$\quad$ Net & -6.8 & 17.3 & 24.1 \\
\hline
\end{tabular}

Source: Federal Reserve Bulletin, vol. 67 (December 1981), pp. A60-61, and vol. 70 (July 1984), pp. A62-63. a. Net of Middle East oil exporters.

Note that the current account deficits in the Asian countries were proportionately as large as, or even larger than, those in Latin America. The difference across countries was not therefore so much in the current account but instead in the capital account and particularly in the division between public and private capital. (A recent IMF study has similarly concluded that internal fiscal and monetary management, rather than external shocks, is most important in separating those countries that did and did not experience the need to renegotiate foreign debt.) ${ }^{6} \mathrm{My}$ table 2 shows this same point in a graphic way. There we see the net position of U.S. banks vis-à-vis the Latin American and Caribbean countries, on one hand, and vis-à-vis the Asian countries on the other. U.S. bank net claims on Latin America rose by $\$ 49$ billion between 1978 and 1983, while net claims on the Asian countries rose by $\$ 24$ billion. The big difference in the two regions, however, is not in the net claims but rather in the gross claims and liabilities. The U.S. banks' gross liabilities to Latin America rose by $\$ 83$ billion at the same time that gross claims rose by $\$ 131$ billion. The banks provided a special sort of intermediation: the private sectors of Latin America made offshore dollar loans to the Latin American public sectors.

Although the financial differences between Latin America and Asia are crucial in my view, I do not want to leave the impression that they explain everything. Nor would Diaz-Alejandro or Rudiger Dornbusch let me do so. There are at least two points that need substantial

6. See D. J. Donovan, "Sources of External Servicing Difficulties" (IMF, December 1983). 
qualification. First, Brazil hardly fits the bill set out so far. Its system of exchange controls prevented enormous capital flight and the exchange rate was not grossly overvalued (it is likely, though, that some capital flight is hidden in underinvoiced exports and correspondingly exaggerated current account deficits). Brazil does seem to fit the more traditional view of the debt crisis as outlined in the second section of DiazAlejandro's paper. It suffered sharp terms of trade and interest rate shocks during 1979-81, which it met by reducing savings rather than real wages (the national savings rate fell from an average of 24.4 percent during 1970-78 to 18.2, 20.2, and 19.1 percent in the next three years). By 1982 it was burdened with the world's largest external debt and thus not surprisingly fell prey to the credit cutoff and financial panic that emanated from Argentina and Mexico. Even though Brazil did not suffer directly from capital flight, it probably suffered indirectly by sharing the cutoff in bank lending to Latin America since mid-1982. The second point refers to the Asian economies. One significant structural difference between Latin America and Asia that bears emphasis is the much greater macroeconomic openness of the Asian economies. While debt-GNP ratios are comparable across the two groups of countries, debt-export ratios are invariably lower in Asia. Thus, creditors will naturally perceive the likelihood of debt-servicing difficulties to be less for the Asian countries, all other things, such as debt-GNP ratios, being equal.

Diaz-Alejandro stresses the capital flight problem, though almost as an interesting afterthought, in the fourth section of the paper, where he addresses "public debt, private assets." He also has some important things to say about the OECD role in restricting tax havens and illegal capital flows. What I find missing, however, is a more integrated macroeconomic treatment of the issue that investigates the conditions under which at least some of the capital flight could be reversed so that the existing public external debt in dollars could be partially funded as internal debt in local currencies. Even a few billion dollars of reverse capital flow could greatly brighten the current debt situation.

Presumably, capital inflow from the private sector can be encouraged if the borrowing countries' public finances are improved. After all, the degree of confidence in the bolivar or peso depends on the market's judgment as to the share of public debt that will be serviced via tax revenues, versus seignorage, versus currency reform. The IMF focus on budget deficits is therefore, contrary to what Diaz-Alejandro suggests, 
more than a ploy to improve trade balance surpluses. It is a crucial step in permitting the long-term, noninflationary servicing of the Latin American public debt, which in turn is important for restoring the private-sector confidence in local currency assets. Where I would agree with Diaz-Alejandro in criticizing IMF programs is that they have made insufficient allowance for the strong, contractionary real output effects of the needed fiscal austerity. Fiscal contraction must be coupled with a realistic plan of real exchange rate depreciation so that the loss of output in nontradables is offset by increased production of tradables. Fiscal contraction without real exchange rate depreciation causes huge output losses and does little to restore long-term confidence in the public finances. This is a lesson from Chile in the early 1980s. Chile actually achieved budget surpluses in 1979 and 1980; instead of restoring confidence, the budget policy contributed to the enormous output decline after 1981 .

It remains to ask how much can be accomplished by a package of fiscal contraction and real exchange rate depreciation. The paper does discuss at length the likely trade balance gains from a real exchange rate change, but I suspect that the econometric estimates of those gains, in tables 12 and 13, are biased downward. Exports and imports should depend not only on the real exchange rate vis-à-vis the United States, as in Diaz-Alejandro's equations, but on the relative price of tradables to domestic wages, a factor which Diaz-Alejandro ignores. I suspect that the supply effect of increased profitability in exportables goes a long way to explain why in 1984 Brazil's manufactured exports are running 68 percent higher and Mexico's non-oil exports are 56 percent higher than their 1983 levels. ${ }^{7}$

Similarly, Diaz-Alejandro does not mention the scope for import substitution that is now present after several years of profit squeeze in the import-competing sector. In Venezuela, for example, the textile sector is now booming at the free rate of twelve bolivars per U.S. dollar after being crushed by imports in the period of the overvalued currency. Import penetration in textiles has declined from about 70 percent of the

7. These data refer to the values of exports for the first four months of 1984 over the same period in 1983. See W. R. Cline, "Current Prospects for International Debt," in International Debt: Systemic Risk and Policy Response (Washington, D.C.: Institute for International Economics, 1984), p. 154. 
domestic market to about 30 percent in two years. This experience will be replicated throughout the region, and it would be useful to have estimates of its importance alongside the projections for export growth.

There is one more point in the paper that warrants comment. DiazAlejandro makes several disparaging references to the credit cartel that now governs the international capital markets. It is even christened the "international credit orderly marketing arrangement." I think these comments miss their mark. For countries with unimpaired creditworthiness, such as in Asia, bank lending continues to be under highly competitive terms. The focus of the cartel is not the overall market but only those countries undergoing debt rescheduling, as in Latin America. In those cases, cartel behavior involves refinancing of existing debts. The motivation of the cartel is to prevent individual banks from free riding on refinancing by other banks instead of imposing monopoly prices on new credit. The generous terms of Mexico's recent rescheduling make that point clearly. Thus Diaz-Alejandro's call for a quick end to the credit cartel should not be viewed as an action that depends basically on the banks but rather on the debtors, since the need for a cartel will subside once the free-rider problem in international lending is eliminated by improved creditworthiness.

\section{General Discussion}

The role of exchange controls and the prospects for the return of the private capital that had fled Latin America provoked some sharp disagreements. Stanley Fischer contended that there is no incentive for the flight capital currently invested in U.S. Treasury bills to return, particularly since it is unrecorded by the home authorities and is thus not being taxed. He reasoned it might be appropriate for the U.S. government to provide records of ownership to Latin American governments, perhaps as a reward to those countries that get their current accounts in order. Fischer concluded that capital controls are necessary for Latin America in order to keep capital within the region when problems arise.

Henry Wallich disagreed, arguing that flight capital might well return and that exchange controls would worsen that prospect. Latin Americans are borrowing at high rates at home to continue their business expansion, 
even though they have money abroad. If the cost of borrowing becomes high enough, the funds could flow back. But a necessary precondition for a return of capital is the assurance that the investor can get back out again, without being blocked by exchange controls. Wallich also reasoned that informing foreign governments of the ownership of U.S. securities would only drive that capital underground and not back to the home country. Robert Lawrence agreed that flight capital could return to Latin America given the proper incentives. These included freeing up domestic interest rates to make returns attractive and establishing realistic exchange rates so the exchange risk did not inhibit investment. Jeffrey Sachs replied that if exchange rates were allowed to float, or at least government interventions were minimized so that exchange rates were allowed to fluctuate more freely during a crisis, there would be no need for the exchange controls that Fischer advocated.

Diaz-Alejandro supported Fischer's remedy of exchange controls. He asserted that, for Latin America, credible monetary and fiscal policies are necessary but by themselves are not enough to eliminate speculative flows and that freely fluctuating exchange rates are simply not credible. He noted that exchange controls exist in most European countries and argued that Latin American countries need to have exchange controls in place so that they can be enforced in a time of crisis.

Rudiger Dornbusch endorsed Paul Krugman's proposal that the IMF programs to the Latin American countries should put more emphasis on expenditure-switching policies than on the traditional remedy of expenditure-reduction policies. Brazilian non-oil imports have fallen by 60 percent since 1980, and investment goods accounted for only 25 percent of that reduction. In Dornbusch's opinion, these figures reveal the versatility of Brazilian producers in producing import substitutes in response to the favorable exchange-rate depreciation. The best growth policy for the Latin American countries in the face of a foreign exchange constraint is to control imports through quotas, tariffs and an import authority "who loses the application forms," in order to induce growth of import-competing industries. James Duesenberry questioned Dornbusch's proposals because many of the present troubles of the less successful developing countries are due to past policies of import substitution. Import substitution may be a tempting short-run remedy for unemployment, but the growth prospects of the economy cannot be 
increased by being saddled with hothouse industries. Diaz-Alejandro agreed with Dornbusch that there is room for import substitution, but he argued that the desirability of import substitution depends on the mechanisms used to induce it. A vexing problem with import substitution is that it often comes at the expense of export-led growth, which history has shown to be more productive in the long run. 